\title{
MORAL LUCK: EXPLOITING SOUTH AFRICA'S POLICY ENVIRONMENT TO PRODUCE A SUSTAINABLE NATIONAL ANTIRETROVIRAL TREATMENT PROGRAMME
}

\author{
Courtenay Sprague* \\ STU WOOLMAN**
}

\begin{abstract}
What kinds of social policy interventions will enable South Africa to offer a universal, free and sustainable antretroviral treatment programme? Some commentators assert that government's best chance at offering such a programme will require the use of compulsory licenses and that the state's failure to make use of such a weapon is a failure to discharge its constitutional duties. The authors demur. The threat of a compulsory license is only as good as the ability to make use of such a license. South Africa currently lacks the basic science community, reverse engineering capacity and fine chemicals industry necessary to make good on such a threat. The government's best hope for discharging the duties imposed by the Constitution is a systematic, structural intervention: the implementation of a socio-industrial policy that leverages existing industrial capacity and voluntary licenses in a manner that generates price reductions and offers an uninterrupted sustainable local supply. However, voluntary licenses will only create downward pressure on prices when South Africa is able to establish a robust generics pharmaceutical industry. Such an industry can be created with appropriate tax relief, investment credits, technology transfer and assured access to active pharmaceutical ingredients. South Africa's industrial, legal and financial resources can thereby be profitably exploited in a manner that progressively achieves a comprehensive and coordinated antiretroviral treatment programme.
\end{abstract}

\footnotetext{
* Lecturer, Graduate School of Business Administration, University of the Witwatersrand, Johannesburg.

** Senior Lecturer, School of Law, University of Pretoria; Research Associate, Centre for Human Rights, University of Pretoria. The authors wish to express their gratitude to the following individuals for their intellectual contributions to this article: Rashmir Balasubramaniam (Gates Foundation), David Bilchitz (Ross Kriel Attorneys), Andy Gray (University of KwaZulu-Natal), Fanie Marais (CSIR), Heather McKay (Carnegie Corporation of New York), Kasturi Moodaliyar (University of the Witwatersrand, School of Law), Stavros Nicolau (Aspen Pharmacare), reviewers for the SAJHR and from the South African government.
} 


\section{INTRODUCTION}

Two facts about HIV/AIDS in South Africa are well-known. First, over five and a half million adults and children are infected. Second, a lack of political will leaves our society without the kind of treatment programme that might turn a deadly disease into a chronic illness. ${ }^{1}$ Instead, according to current projections, 3.5 million South Africans will die of AIDSrelated infections by $2010 .^{2}$

It doesn't have to be this way. ${ }^{3}$ South Africa possesses the industrial capacity, together with the financial, legal, and human resources necessary to provide a sustainable supply of low cost medicines for those members of our HIV-infected population who require treatment.

How do we know? Brazil. As we demonstrate in part II of this article, Brazil's creation of a successful free, universal antiretroviral treatment ('ART') programme for the HIV-infected population of 660,000 who require treatment is not simply a function of rarefied legal principle married to a conscious, progressive social policy. It is, in large part, an unintended consequence of a series of domestic laws and international agreements not directly linked to the distribution of health entitlements. A long history of exceptions for medicinal patents, a relatively recent

1 In 2004, Mandisa Mbali wrote: '[Denialism] has above all, in my view, led to a serious lessening of the moral authority of the post-apartheid state. Unless the government finally repudiates AIDS denialism and rolls out antiretroviral therapy in the public health sector, it is likely that Mbeki's denialism will eradicate from historical memory many of the positive aspects of his tenure in office.' M Mbali 'HIV/AIDS Policy-Making in Post-Apartheid South Africa' in J Daniel, A Habib \& R Southall (eds) State of the Nation: South Africa 2003-2004 (2003) 326. See also C Simkins 'Can South Africa Avoid a Malthusian Positive Check?' (2001) 130 Daedalus 123; S Friedman, 'On HIV/AIDS, Government Still Speaks with a Forked Tongue' Business Day (6 February 2006); M Crewe 'South Africa: Touched by the Vengeance of AIDS: Responses to the South African Epidemic' (2000) 7 (2) SA J of Int Affairs 23; V van der Vliet 'AIDS: Losing “The New Struggle"?' (2001) 130 Daedalus 151.

2 On the actuarial science that grounds such projections, see Bureau for Economic Research 'The Impact of HIV/AIDS on Selected Business Sectors in South Africa, 2005' (Stellenbosch University October 2005) 11-12, citing R Dorrington and estimates projected by the Actuarial Association of South Africa (ASSA2002) Model. Dorrington states: 'By 2010, despite interventions and treatments, we estimate that nearly 3.5 million South Africans will have died of HIV/AIDS related causes.' See < http://www.assa.co.za $>$. Until recently, South Africa held the dubious distinction of having the largest number of individuals currently living with the virus in a single country. See Joint WHO/UNAIDS Fact Sheet 283 (January 2005). India now holds that position. South Africa must also confront a growing tuberculosis (TB) epidemic. Indeed, TB and HIV co-infection is complicating treatment for both diseases. See Médecins Sans Frontières (MSF) 'The TB/HIV Time Bomb: A Dual Epidemic Explodes in South Africa', $<$ http://www.msf.org $>$

3 Here are four of the chief reasons that we are where we are: (1) a lack of national leadership meant that the treatment programme was begun more than ten years too late; (2) the supply and the stock of ARVs could not become immediately available and accessible to all patients who required them because of government's slowness and delay in rolling out the treatment programme; (3) there was, and there remains, an insufficient supply of health practitioners to staff the programme; (4) sites had to be accredited and infrastructure upgraded prior to the provision of ART. See International Treatment Preparedness Coalition 'Missing the Target: A Report on HIV/AIDS Treatment Access from the Frontlines' (28 November 2005) 3, 75. 
commitment to fairness and to equity in public procurement laws, a robust local pharmaceutical industry, and long-standing state support for a public laboratory capable of reverse engineering active pharmaceutical ingredients ('APIs') constitute just a few of the enabling conditions that have, quite fortuitously, put the Brazilian government in a position to make good the promise of free universal antiretroviral treatment for those who require it. ${ }^{4}$

The results of this programme have been remarkable. By the end of 2001, after just five years, highly active antiretroviral therapy ('HAART') had significantly reduced mortality, morbidity and hospitalisation rates for HIV-infected patients in Brazil such that: (a) occurrence of HIVrelated opportunistic infections decreased by 60 to 80 percent; (b) tuberculosis in HIV-positive patients in the state of São Paulo declined by 75 per cent; (c) mortality rates fell by 50 per cent; and (d) in-patient hospitalisations plunged to 14 per cent of the pre-HAART figures. Perhaps even more astounding is the fact that the actual incidence rates in 2001 were half those predicted by the World Bank. ${ }^{5}$ And contrary to international projections, the state saved some \$1.1 billion ${ }^{6}$ from 1997 to 2001 as a result of reduced hospital admissions. ${ }^{7}$ Best of all: Brazil could claim, by 2003 , that its free, universal ART programme had averted almost 100000 deaths. $^{8}$

4 In spite of the international community's view that Brazil has been a model in its national response to HIV/AIDS, it is important not to glorify or oversimplify the response to the epidemic in Brazil. Government policy changed significantly over the course of the 23 years since the first AIDS case was reported in that country in 1983. In the early years of the epidemic, the federal Ministry of Health failed to respond at all. See R Parker 'Building the Foundations for the Response for HIV/AIDS in Brazil: The Development of HIV/AIDS Policy, 1992 - 1996' (2003) 27 Divulgaçao em Saúde para Debate 143. For example, despite protests from every sector involved in AIDS prevention, the Brazilian government continued to charge a high import tax on condoms in line with protectionist policies aimed at bolstering the national rubber industry. Even after the policy was altered, logistical barriers made regular condom distribution to even high-risk populations unreliable. Ibid.

Brazil's success resulted, in large part, from a bottom-up approach. PR Teixeira, Coordinator of the Brazilian National STD/AIDS programme, observes that Brazil's struggle has been characterised by integrated actions on the part of health professionals, mobilisation by civil society organisations, broad media coverage and a generally favorable public opinion environment. See PR Teixeira 'Universal Access to AIDS Medicines: The Brazilian Experience' (2003) 27 Divulgaçao em Saúde para Debate 184. The number of NGOs working on AIDS in Brazil numbered 600 in 2001. See T Rosenberg 'Drug Companies are Vincible. The AIDS Crisis is Solvable' The New York Times Magazine (28 January 2001).

5 See RA de Mattos, VT Junior \& R Parker 'World Bank Strategies and the Response to AIDS in Brazil' (August 2003) 27 Divulgaçao em Saúde para Debate 215. See also Rosenberg (note 4 above)('In 1994, the World Bank estimated that by 2000 Brazil would have 1.2 million HIVpositive people. In fact, it had half that many.')

6 All dollar figures quoted are US dollars unless otherwise indicated.

7 See MA de vila Vitória 'The Experience of Providing Universal Access to ARV drugs in Brazil' (2003) 27 Divulgaçao em Saúde para Debate 248. See also PR Teixeira (note 4 above) 184.

8 See Joint WHO/UNAIDS Fact Sheet No 283 (January 2005); UNDP “"3 by 5" Progress Report' (December 2004). See also J Galvão 'Brazil and Access to HIV/AIDS Drugs: A Question of Human Rights and Public Health' (2005) 95 (7) American J of Public Health 1110. 
As things now stand, Brazil - a middle-income country - has achieved declining mortality rates comparable to those of the developed countries. (For example, AIDS mortality in the United States declined by 66 per cent over the period 1995 to 2002 with the introduction of $\mathrm{ART}^{9}$.) Thus, despite resistance from the World Bank, ham-fisted political pressure from the US government, threats from multinational pharmaceutical companies and an inhospitable macro-economic and macro-legal environment, Brazil is cited as a leading example of the feasibility of an integrated approach to the epidemic in the setting of a middle-income country. ${ }^{10}$

Can South Africa follow the Brazilian model and scale-up the rollout to meet the needs of the 837,000 South Africans who require antiretroviral medicines ('ARVs')? ${ }^{11}$ The answer is both no and yes. ${ }^{12}$

Note that Brazil was simply the first developing country to demonstrate that a free, universal and viable ART programme could be successfully provided through the public health system. Brazil's powerful example created a paradigm shift amongst the international community as evidence mounted that developing countries with poor resource settings could offer ART while achieving high adherence rates. An initiative funded by the Government of Senegal has maintained relatively high ( 80 per cent - 90 per cent) adherence rates over two to three years. These adherence figures are comparable with those of developed countries. Studies undertaken in Botswana, Uganda and South Africa demonstrate adherence rates comparable to industrialized countries. See I Laniece, M Ciss \& A Desclaux 'Adherence to HAART and its Principal Determinants in a Cohort of Senegalese Adults' (2003) 17 AIDS 103; C Orrell, D Bangsberg, M Badri \& R Wood 'Adherence is not a Barrier to Successful Antiretroviral Therapy in South Africa' (2003) 17 AIDS 1369; S Weiser, W Wolfe \& D Bangsberg 'Barriers to Antitretroviral Adherence for Patients Living with HIV Infection and AIDS in Botswana' (2003) $34 J$ of Acquired Immune Deficiency Syndrome 281.

9 See UNAIDS Living in a World with HIV/AIDS: Information for Employees of the UN System and their Families (2004) 7. A recent study published in the Journal of Infectious Diseases quantified the cumulative survival benefits of AIDS patients in the US on ART. The study concluded that three million years of life have been saved for HIV-infected patients receiving treatment from 1989 to 2003. R Walensky, A D Paltiel, E Losina, L Mercincavage, B Shackman, P Sax, M Weinstein \& K Freedberg 'The Survival Benefits of AIDS Treatment in the United States' (2006) 194 J of Infectious Diseases 11.

10 R Parker (note 4 above) 143.

11 See 'WHO Summary Country Profile For HIV/AIDS Treatment Scale-Up' (June 2005) 1. Current estimates indicate that roughly 74,000 patients had access to anti-retroviral treatment (ART) through public health facilities in South Africa by the end of August 2005. Most patients taking advantage of these services are women. See Report on the Fifth Meeting of the Joint Civil Society Monitoring Forum (29 August 2005) 6; Department of Health 'Monitoring and Evaluation Framework for the Comprehensive HIV and AIDS Care, Management and Treatment Programme for South Africa' (September 2004); HIVAIDS Networking Centre of the University of KwaZulu-Natal (HIVAN) Health Care Newsflash (1 June 2005).

12 Part of the argument for using Brazil to extract lessons learned for South Africa lies in the striking similarities between the two nations. While there are some differences in key indicators such as population size and current prevalence rates, both countries have the same GDP per capita at US $\$ 2,600$, equal rates of literacy at 86 per cent, the same public health expenditure rates of 8.5 per cent, and similar high rates of inequality: South Africa's Gini coefficient is the second highest in the world, after Brazil. (The coefficient measures the unequal distribution in income between rich and poor.) During the post-apartheid era, inequality has increased in South Africa. From 1995 to 2001, the coefficient rose from 0.596 to 0.635 . See J May (ed) Poverty and Inequality in South Africa: Meeting the Challenge (2000) 26-34; UNDP Annual Report for 2004 (2005), <http://www.undp.org > . 
Part of the recipe for Brazil's success lies in conditions for which no one person or regime can take responsibility: Brazil benefits from a social, political, legal, economic and industrial environment that cannot, in very important respects, be replicated here. For example, Brazil lacked meaningful patent protection up until 1996. South Africa did not. Brazil made significant investments in state research laboratories in the 1990s. Such investments would now be prohibitively expensive to undertake in South Africa and would likely yield little tangible return. However, Brazil offers less a discrete set of instructions for how a low- or middle-income country can introduce an ART programme comparable to that found in the developed world, and more a guide as to how a middle-income country like South Africa can exploit its existing industrial capacity, intellectual capital and legal framework to create a sustainable ART programme underpinned by affordable, generic medicines.

In part III below, we describe how the social, economic and legal conditions that currently obtain in South Africa make possible a universal, free ART programme. We begin with the following bromide: that, at a minimum, the Constitution requires the state to provide a truly comprehensive and coordinated ART programme, and that the state has, thus far, failed to put such a programme into place. We contend, then, that the government's best hope for discharging the duties imposed by $\mathrm{s}$ 27 is a socio-industrial policy that leverages existing industrial capacity and voluntary licenses in a manner that generates price reductions. Such downward pressure on prices - in concert with other government programmes - should secure the greatest amount of lifesaving medicines for the greatest number of South Africans. ${ }^{13}$

The rudiments of such a programme are, indeed, already on the books. ${ }^{14}$ The National Drug Policy states that the procurement and sustainable supply of low cost medicines for the entire HIV-infected population requiring treatment are essential for a successful rollout, and recommends that South Africa exploit its existing manufacturing

13 The provision of an affordable, sustainable supply of ARVs is a critical component of a successful ART programme, and is thus the focus of this article. We recognise the importance of human resources and infrastructure, and most importantly, government leadership as necessary conditions for the success of the kind of ART programme contemplated here.

$14 \mathrm{We}$ must also acknowledge at the outset the crucial role played by civil society in the advancement of ART policy in South Africa. We believe readers of the SAJHR are wellacquainted with that recent history. Indeed, people outside of South Africa are quite familiar with the politics surrounding access to ART in South Africa. As the popular US website, Salon.com, observes, 'the South African government's slow response to the AIDS crisis South Africa's hesitations and missteps on the issue are well-chronicled.' 'The AIDS Drug Warrior' Salon.com (18 June 2001) available at < http://www.salon.com $>$. This article, then, does not attempt to rehearse the well-established literature on the campaign for access to antiretrovirals in South Africa - led chiefly and successfully by the Treatment Action Campaign (TAC) and the AIDS Law Project (ALP). Instead, we offer an additional - and in many ways compatible - policy response to the particular problem of providing low-cost ARVs for the entire South African population. 
capacity to produce low-cost generics. ${ }^{15}$ The national Department of Health's Operational Plan for Comprehensive HIV and AIDS Care, Management and Treatment Programme echoes similar themes. For the state to satisfy constitutional desiderata, it must make a genuine effort to implement important features of both documents.

Not only are the makings of a robust policy part of the public record, we will show that South Africa possesses the requisite space to manoeuvre successfully within the existing regulatory structure and the intellectual property regime ('IPR') that govern the manufacture and the distribution of generic ARVs. Although the Agreement on Trade-Related Aspects of Intellectual Property Rights ('TRIPS') and the Patent Amendment Act have tightened the current intellectual property rights regime - just as public health demand for existing and new medicines has grown - international and domestic law retain sufficient flexibility for South Africa to meet its public health objectives and its constitutional obligations.

In terms of drug pricing, the dominant rate-limiting factor is a lack of competition amongst suppliers. We show that the state's current ARV rollout programme evinces a sub-optimal approach to price negotiations because South Africa has not constructed an industrial policy that promotes the local production of generic ARVs. ${ }^{16}$

Where we differ markedly from other authors who have written in these pages is on the extent to which compulsory licenses - or the threat of such licenses - can be used to leverage lower prices. ${ }^{17}$ Contrary to Bollyky's view, the threat of a compulsory license is only as good as the ability to make use of such a license. South Africa currently lacks that capacity. South Africa does not as yet possess a basic science or research community capable of undertaking the complex task of reverse engineering required for the creation of generic ARVs. There is no local fine chemicals industry capable of producing all of the APIs required for the mass manufacture of ARVs. In the absence of these two prerequisites alone, the threat of compulsory licenses to lower drug prices is empty. Moreover, we would argue that, as things currently stand, such a threat will not achieve the goal - a robust and sustainable ART programme to meet the needs of the HIV-infected population who require treatment for life. As we shall see, Bollyky's largely rhetorical battle with multi-

15 Government of the Republic of South Africa, National Drug Policy (1996).

16 The provision of an affordable, sustainable supply of ARVs is a critical component of a successful ART programme, and is thus the focus of this article. We recognise the importance of such factors as human resources, infrastructure and, most importantly, government leadership to ensure the success of ART programmes.

17 T Bollyky 'Balancing Private Rights and Public Obligations: Constitutionally Mandated Compulsory Licensing of HIV/AIDS Related Treatments in South Africa (2002) 18 SAJHR 530 . 
nationals and the South African government has blinded him (and others) to the virtues of voluntary licenses. ${ }^{18}$

Voluntary licenses minimise the potential for re-exportation of drugs and curtail, as the World Health Organisation (WHO) notes, the real dangers to patients associated with black and grey markets in ARVs. ${ }^{19}$ In the context of a legal regime that effectively bars re-exportation of drugs to primary markets in developed countries, many multinational companies (patent-holders) provide voluntary licenses with no royalty requirements and complete tech transfers. ${ }^{20}$ From the perspective of South African policy-makers and local manufacturers, these agreements place ARV production on a solid legal footing and avoid legal wars of attrition.

Because little attention has been paid to voluntary licenses, critics of government policy have also overlooked South Africa's increasing capacity to produce generic ARVs for both domestic and sub-Saharan African markets. We review the economic fundamentals that must be in place in order for South Africa to establish a robust generics pharmaceutical industry for ARVs. Unlike Brazil, local production of APIs is not as important in South Africa as is continued access to them. While India, China, Brazil and South Korea, amongst others, are capable of supplying many of the APIs required to produce ARVs, what South Africa requires - and the Constitution demands - is the proper mix of policy and tax incentives to support a generic pharmaceutical industry for ARVs that 'owns the cow'. The Department of Trade and Industry's recent Strategic Investment Programme ('SIP') provided the incentive to construct at least one major plant capable of producing formulated

18 Voluntary licences (VLs) enable manufacturers to produce and sell generic versions of patented products.

19 A World Health Organisation survey of 20 countries, conducted between January 1999 and October 2000, found that 60 per cent of counterfeit medicine cases occurred in poor countries and 40 per cent in industrialised countries. The US FDA estimates that 10 per cent of pharmaceuticals worldwide are counterfeit medicines and 25 per cent of medicines in developing countries are fake or substandard. For pharmaceutical companies, the primary concern is that counterfeits cause their efficacious products to be perceived as being harmful or ineffective. See 'Counterfeit Medicines' WHO Fact Sheet no. 275, revised February 2006 $<$ http://www.who.int/mediacentre/factsheets/fs275/en $>$.

20 Technology transfer is a process that entails the movement of codified knowledge, expertise and management techniques. Technology transfers can occur through formal as well as informal methods. For example, informal technology transfer is executed by imitation, and does not generally involve a legal agreement or monetary transaction. A formal technology transfer is largely a commercial operation or venture underpinned by the necessary legal and financial arrangements. Formal technology transfer may include foreign direct investment (FDI), joint ventures, wholly owned subsidiaries, licensing, technical-service arrangements, joint research and development (R\&D) arrangements, training, information exchanges, sales contracts and/or management contracts. See WTO 'Agreement on Trade-Related Aspects of Intellectual Property Rights', <http://www.wto.org/english/tratop_e/trips_e/t_agm0_e.htm > ; UNCTAD-ICTSD 'Intellectual Property Rights, Implications for Development Policy Discussion Paper' (2003). 
generic ARVs. ${ }^{21}$ We will demonstrate that the proper macro-industrial policy - one committed to increasing local manufacturing capacity and voluntary licensing - will put South Africa in the best possible position to produce the requisite level of ARV and TB medicines for a successful domestic ART programme. ${ }^{22}$ Moreover, we argue that with appropriate government tax relief, investment credits, technology transfer and assured access to APIs, the pharmaceutical industry in South Africa could gain a comparative advantage as a producer of ARVs become a supplier of low-cost pharmaceuticals to the rest of the continent. ${ }^{23}$

South Africa is, therefore, in a position to make its own luck. It may not be Brazil, but its industrial, legal and financial resources can all be profitably harnessed in a manner that progressively realises the comprehensive and coordinated ARV programme that s 27 and more general considerations of social justice demand.

\section{THE HISTORICAL, POLITICAL, SOCIAL, ECONOMIC AND LEGAL CONDITIONS THAT MADE POSSIBLE BRAZIL'S POLICY OF UNIVERSAL, FREE ANTIRETROVIRALS}

A cursory reading of the secondary literature might lead students of the subject to the conclusion that Brazil's national AIDS programme (NAP) was solely a consequence of a constitutional right to health, ${ }^{24}$ a savvy social movement ${ }^{25}$ and the progressive health agenda of the government. We do not wish to deny that the right to health and a politics of solidarity were necessary conditions for the rollout. We contend, however, that an emphasis on abstract legal principle and politics of solidarity obscures how the unintended consequences of a series of domestic laws and international agreements not directly linked to the distribution of health entitlements conspired with a relatively unique mix of economic, historical and political conditions to produce Brazil's largely successful experiment in free, universal access to ARVs.

21 Government of the Republic of South Africa (Department of Trade and Industry) 'Report to Parliament: Strategic Industrial Projects (SIP) April 2002-March 2004' (2005); Interview with Stavros Nicolaou, Aspen Pharmacare, 28 February 2006.

22 South African companies have already signed voluntary license agreements for a panoply of first, second and third line drugs.

23 Out of a total of 90 developing countries submitting national HIV/AIDS plans to the World Health Organisation in 2002, 60 per cent had incorporated ART into their national strategies or had defined specific ART targets. See S Lucchini, B Cisse, S Duran, M de Cenival, C Comiti, M Gaudry, JP Moatti 'Decrease in Prices of Antiretroviral Drugs for Developing Countries: from Political "Philanthropy" to Regulated Markets?' (June 2003) 170-173, $<$ http://www.iaen.org/papers $>$.

24 Constitution of the Federative Republic of Brazil (1988), Chapter II, Social Rights, Article 6 states: 'Education, health, work, leisure, security, social security, protection of motherhood and childhood, and assistance to the destitute, are social rights as set forth by this Constitution.'

25 See Teixeira (note 4 above) 184 


\section{(a) Good governance as an economic stimulant: how a fair public procurement policy jump-started the local pharmaceutical industry}

Our story begins with Brazil's transition from military dictatorship to constitutional democracy in 1988 . Here too is where the standard account starts. While the standard account emphasises the inclusion of a (potentially justiciable) right to health in the 1988 Constitution, the more interesting feature of this transition is the shift from a corrupt, autocratic dictatorship to an open, transparent and accountable democratic state. The pre-1998 Brazil, governed by a military junta, possessed all the hallmarks of a crypto-fascist state. Plutocratic rule stultified competition, especially with respect to government tenders. Contracts were handed out to companies owned by government officials or their friends.

The new constitution's commitment to democracy and the rule of law meant a concomitant commitment to rooting out the corruption that long-plagued both the public and the private sectors. The 1988 Constitution states that public procurement of 'goods and services must comply with the principles of legality, impartiality and transparency. ${ }^{26}$ Several early decisions handed down by the federal courts confirmed the justiciability and the efficacy of these principles. ${ }^{27}$

These generic principles of fairness were extended by the 1993 Call for Tender Law. ${ }^{28}$ According to the Tender Law, all government contracts had to proceed by way of public and standardised solicitation of the goods to be acquired under conditions of fair competition. The Tender Law also attempted to extend the benefits of competition beyond the mere creation of markets in public goods. It aimed to ensure that many of the competitors in these markets were Brazilian companies, by giving preference to '(i) goods produced or services supplied by domestic companies; (ii) goods produced in the country; (iii) goods produced or services provided by companies established in Brazil. ${ }^{29}$

This system of unadulterated 'national preference' was, as Orsi, Hasenclever, Fialho, Tigre, and Coriat note, short-lived. ${ }^{30}$ A constitutional amendment in 1995 eliminated the protection afforded 'national

26 RR Rios 'Legal Responses to the HIV/AIDS Epidemic in Brazil' (2003) 27 Divulgaçao em Saúde para Debate 228; See also J Galvão 'Brazil and Access to HIV/AIDS Drugs: A Question of Human Rights and Public Health' (2005) 95 (7) American J of Public Health 1110; F Orsi, L Hasenclever, B Fiahlo, P Tigre \& F Coriat 'Intellectual Property Rights, Anti-AIDS Policy and Generic Drugs: Lessons from the Brazilian Public Health Programme' (2003) Paper from International AIDS Economics Network < http://www.iaen.org/papers > .

27 Rios (note 26 above) 228.

28 Ibid.

29 Ibid.

30 Orsi et al (note 26 above) 117-118. 
products' and opened most tenders to foreign competition. ${ }^{31}$ While the liberalisation of trade was a bracing tonic for Brazilian industry, the opening up of the South American country to full-fledged market competition remained an important stimulus for growth in the pharmaceuticals industry. And it is this growth, as we shall see, that created the conditions under which subsequent local production of ARVs could more readily occur.

\section{(b) Intellectual property rights as an economic stimulant: how Brazil's IPR regime created local capacity to produce generic ARVs}

A parallel set of conditions, unrelated to the political transition, provided a different sort of traction for the local pharmaceutical industry. In 1971, Brazil suspended the laws governing intellectual property for pharmaceuticals. The state exploited this suspension by creating a parastatal called Companhia de Desenvolvimento Tecnológico (CODETEC). CODETEC partnered academics with technicians from the Ministry of Industry and Trade. CODETEC's function was to provide the institutional home for academics and professionals engaged in the reverse engineering process of the key components of all drugs: active pharmaceutical ingredients ('APIs'). The goal was to acquire the capacity to produce synthetic variations on APIs. Once CODETEC had discovered how to create the synthetic version of an API, the knowledge was transferred to entities in the private sector that possessed the production capacity to manufacture the final product. ${ }^{32}$

Brazil's quarter century of non-compliance with international intellectual property norms had the obvious benefit of providing 'products' that a local pharmaceutical industry could manufacture. The profits from such production created the enabling conditions for the manufacture of new lines of products. ${ }^{33}$ As a result, Brazil currently has 19 local firms and 9 public laboratories capable of producing ARVs. ${ }^{34}$ What the 1971 to 1996 period of non-compliance did not do, however, was address Brazil's limited capacity with respect to the production of the raw materials required for APIs. This limited capacity significantly constrains its ability to produce generic ARVs. ${ }^{35}$ It also makes Brazil dependent on

31 See Orsi et al (note 26 above) 117, 128. See also M Cassier \& M Correa 'Patents, Innovation and Public Health: Brazilian Public-Sector Laboratories' Experience in Copying Aids Drugs' (2003) Paper from International AIDS Economics Network 89-107, < http://www.iaen.org/ papers/>.

32 See Orsi et al (note 26 above) 122.

33 See Orsi et al (ibid) 122-124; Cassier \& Correa (note 31 above) 93.

34 See Orsi et al (ibid) 123-124.

35 Note that Brazilian law allows for the marketing of two reference copies of a drug: (1) similar drug products and (2) generic drug products. Generic drugs must meet exacting bioavailability and bio-equivalency tests to secure registration in Brazil. Similars do not need to meet such stringent tests. As a result, most off-patent ARVs in Brazil are registered as similars and not generics. See Orsi et al (ibid) 118-119. 
countries with that capacity — namely India and China — who may not always be in a position, legally or politically, to provide the APIs or the raw materials required for their production. ${ }^{36}$ That said, downstream diversification of the world's 6th largest petrochemical industry through the development of new fine chemical processes and technology production - promises a future of enhanced API production capacity for Brazil. ${ }^{37}$

Two relatively recent developments in IPR further diminished Brazil's capacity to produce sufficient APIs for a sustainable and effective programme of free, universal access to ARVs required for the treatment of AIDS. The 1996 Patent Law brought the Brazil pharmaceutical industry back within the domain of legal constraint imposed by TRIPS and other international agreements regarding intellectual property rights. Although the law does permit Brazilian companies to continue production of drugs - and thus ARVs - in circulation prior to 1996, its retroactive deposit application has meant that international pharmaceutical companies could seek registration of 'patents . . valid abroad or pending in Brazil' at the time of the law's passage. It also means that international drug companies could both patent their new drugs and enforce their patents in Brazil after the law's enactment. At the same time, however, art 68 of the Brazilian Patent Law - echoing TRIPS enables Brazil to issue compulsory licenses where a public health crisis so warrants. $^{38}$

The law's divide between the past (pre-1996) and the future (post-1996) has had profound consequences for the ARV procurement strategy pursued by Brazil's Ministry of Health. Only drugs in circulation prior to 1996 in Brazil - or those whose patents have not yet been enforced subsequent to the 1996 Patent Law's enactment - can be copied for local use. The patent law is, however, only one of an array of deleterious consequences of trade liberalisation for the Brazilian pharmaceuticals industry. According to Orsi and others, Brazil has lost a significant percentage of 'its industrial capability to produce synthetic intermediates and raw materials' for ARVs and other pharmaceuticals. ${ }^{39}$ Projects initiated in the 1980s, when Brazil's industry was relatively cosseted, can no longer compete on a playing field levelled by the elimination of tariff and non-tariff barriers to trade. This loss of production capacity, married to restrictive patent laws and a dependence on foreign sources of APIs,

36 For example, the Brazilian company, Labogen, is capable of producing APIs, but it may be driven out of business due to its inability to compete with Asian suppliers. See Orsi et al (note 26 above) 117 .

37 The Brazilian government's success is due in no small measure to its willingness to link its health policy and its industrial policy in the service of HIV-infected Brazilians. See Orsi et al (ibid) 117; Cassier \& Correa (note 31 above) 92.

38 See Orsi et al (ibid) 117; Cassier \& Correa (note 31 above) 92

39 See Orsi et al (ibid) 117. 
will, in future, limit Brazil's ability to leverage lower prices through threatened use of compulsory licenses. ${ }^{40}$

While international competition and trade liberalisation has blunted the growth of a local synthetics industry, Brazil's commitment of significant state resources to the free, universal rollout of ARVs and extant local capacity for production of generics means that the fundamentals required for the expansion of the resource base for the manufacture of ARVs still exist. However, Brazil must carefully husband these resources should it wish to remain in a position to pressure other states and multinational pharmaceutical companies into the knowledgesharing and asymmetric pricing arrangements that currently enable the Brazilian fiscus to make good on its current commitments.

\section{(c) Priming the pump: how public laboratories create the capacity for local production of generics and make effective the threat (or the use) of compulsory licenses}

The Brazilian government has been quite aware of the precariousness of its bargaining position vis-à-vis TRIPS, the multinational pharmaceutical companies, and the quickly closing window of opportunity it has had to secure access to APIs and generics from countries such as India, China and South Korea. ${ }^{41}$ Perhaps the boldest step, and the step most likely to continue to pay dividends in the near term, was the Brazilian health ministry's decision in 1997 to fund efforts of the Far-Manguinhos stateowned pharmaceutical laboratory to reverse engineer pharmaceuticals used in the treatment of HIV/AIDS. ${ }^{42}$ As Cassier and Correa note, the primary objective of this state-sponsored generics initiative was the realisation of lower prices for a range of agents including APIs so that the

40 But see E Combe, E Pfister \& P Zuniga 'Pharmaceutical Patents, Developing Countries and HIV/AIDS Research' (2003) Paper from International AIDS Economics Network 151, 153, 154$159,<\mathrm{http}: / /$ www.iaen.org/papers/ $>$. The authors contend that the strengthening of patent protection in developing countries creates only the most marginal increase in research innovation incentives. If this is true, then it limits the rhetorical force of pharmaceutical manufacturer arguments that universal enforcement of patents is required for universal access to treatment for HIV/AIDS to be possible. For example, Africa constitutes only 2 per cent of the world market in pharmaceuticals. As we note in the text, what multinational pharmaceutical companies generally want is a legal regime that bars re-exportation of drugs (also called re-importation) in a manner that undercuts profits in their primary markets in the developed world.

41 See B Mercurio 'TRIPS, Patents and Access to Life-Saving Drugs in the Developing World' (2004) 8 Marquette Intellectual Property LR 211.

42 The primary role of antiretroviral therapy for HIV-infected patients is to delay or to prevent the onset of acquired immune deficiency syndrome, and ultimately, death. ART is thus required for life since antiretrovirals cannot eradicate HIV. Importantly, as drug resistance begins to occur in patients on ART, mutations of the virus require that new classes of drugs are developed and deployed to patients in a timely fashion. See R Wood 'Antiretroviral Therapy' in SS Abdool Karim \& Q Abdool Karim (eds) HIV/AIDS in South Africa (2005) 504 As more effective new drugs are patented in accordance with the greater protection required 
NAP remained sustainable. ${ }^{43}$ However, the manner in which FarManguinhos' drug production efforts have secured — and will continue to secure - lower prices is not straightforward.

Far-Manguinhos accounts for 40 per cent of current ARV production in Brazil. (The balance is produced by other state-owned laboratories and private sector companies.) But Far-Manguinhos does not, in the main, replicate drugs that then go into production and out into circulation. Although Far-Manguinhos did engage in such a process of knowledge acquisition and product manufacture prior to 1996, the law post-1996, as we have seen, prevents wholesale copying and production of patented drugs. What then have been the benefits of the 50 drug formulae reverse engineered since $1996 ?^{44}$

They are three-fold. First, the process builds national capacity. This capacity has the intrinsic virtue of having created an institution capable of conducting research and development on existing pharmaceuticals and new agents in-country. It has the extrinsic virtue of ensuring knowledge and technology transfer to other players — public and private — in Brazil's pharmaceuticals industry.

by TRIPS (as of January 1, 2005 the ten-year transition period afforded under Article 65 comes to a close), they may remain out of reach for populations in developing countries unless low-cost generic versions can be provided. Patients begin treatment with first line drugs and require second line drugs if they become resistant to the first class of medicines. The WHO published a manual in 2002 with recommendations for treatment regimens in resource limited settings, which was updated in 2004. The WHO treatment guidelines for ART in resourcelimited settings are a nucleoside analogue reverse transcriptase inhibitor (NRTI), stavudine (d4T) or zidovudine (ZDV); a NRTI such as lamivudine (3TC); and a non-nucleoside reverse transcriptase inhibitor (NNRTI), nevirapine or efavirenz. Second line drugs allow for fixeddose combinations, which are simply easier to take and thus facilitate patient adherence. Dr Eric Goemare, of Médecins sans Frontières (MSF) in South Africa, argues: 'It's a common phenomenon linked to the mutation of the retrovirus: after having taken the drugs for more than four years, patients develop resistance. This is already a problem for 17 percent of people on ARV treatment in [MSF's Khayelitsha project] in South Africa, and will become the rule in the next few years.' See 'Interview with Eric Goemare: Africa New Drugs Needed Urgently' IRIN PlusNews (UN-OCHA Integrated Regional Information Networks)(14 December 2005). While many first line ARV drugs are now off-patent, second line drugs are not. This state of affairs obviously has a bearing on the future costs of national ART programmes in the developing world and reinforces the appeal of voluntary licenses.

43 Cassier \& Correa (note 31 above) 89-93.

44 See Orsi et al (note 26 above) 117. South Africa has received the benefits of Far-Manguinhos' work as well. MSF received approval from the Medicines Control Council to use generic versions of AZT, 3TC and nevirapine in MSF's Khayelitsha treatment programme. The medicines were produced by Far-Manguinhos and were secured though MSF's agreement with the Brazilian Ministry of Health. MSF's pilot project in Khayelitsha township was initiated before South Africa's national ARV rollout and demonstrated the feasibility of offering ART in South Africa on a national basis. MSF states: 'The Khayelitsha ARV treatment project was initiated to demonstrate that treating HIV/AIDS with ARV drugs in primary health care setting[s] and in a resource-limited environment is feasible and replicable.' See MSF South Africa, the Department of Public Health at the University of Cape Town, the Provincial Administration of the Western Cape Province 'Antiretroviral Therapy in Primary Health Care: Experience of the Khayelitsha Programme in South Africa' Geneva: WHO (2003). Accessible from the WHO website, <http://www.who.int/hiv/pub/prev_care/pub38/en > ; MSF 'Brazilian Generic Drugs in South Africa - The Background' 29 January 2002. 
Such transfer strengthens what we have already seen to be a knowledge-intensive sector. Secondly, and more importantly for our immediate purposes, the process operates as an insurance policy. Should multinational firms refuse to supply ARVs at a cost that makes Brazil's programme sustainable, the government retains the capacity to produce generic ARVs. That is, the capacity of Far-Manguinhos to reverse engineer ARVs ensures that Brazil's threat to use compulsory licenses remains credible. Moreover, given the uncertainty surrounding how TRIPS enforcement will affect the importation of generics from India, China and elsewhere, the ability of Far-Manguinhos to produce the end product - if not all of the APIs themselves - gives Brazil a certain degree of security should it be forced to go it alone. Thirdly, as Lucchini notes, meaningful price decreases only occur when 'buyers have the power to substitute between multiple suppliers. ${ }^{45}$ Brazil's introduction of generic substitutes and its willingness to invest in future drugs that may never come on line creates the spectre of multiple suppliers and, consequently, a continued downward trend in price. ${ }^{46}$

At a somewhat higher level of abstraction, the Brazilian government's decade's worth of investment in Far-Manguinhos reflects its ability to recognize the complexity of the political-economic landscape and to construct long-term strategies to cater for a variety of different contingencies. It also stands as an implicit critique of the South African government's refusal to engage in anything that resembles a coordinated and comprehensive programme to ensure that the health needs of its citizenry are met. ${ }^{47}$

45 See Lucchini et al (note 23 above) 171. See also S Lucchini, C Comiti, M de Cenival, D Ségolène, Y Souteyrand \& JP Moatti 'Determinants of Prices of ARV Drugs in Developing Countries: The Impact of Increased Competition and Intellectual Property Rights' (2002) XIV International AIDS Conference.

46 See Lucchini et al (note 23 above) 202.

47 Marta Darder of MSF and Andrew Boulle of the University of Cape Town offer the powerful anecdote of a patient in Khayelitsha who exemplifies some of the challenges patients in many developing countries face. The patient takes a first-line treatment that includes zidovudine, lamivudine and nevirapine. Zidovudine and lamivudine come together in a single pill called a fixed dose combination, which means the patient only needs to take two pills per day. However, if this patient is one of the 10 per cent to 30 per cent who will become resistant, he will then begin second-line treatment, which according to Darder and Boulle will consist of didanosine, ritonavir-boosted lopinavir and tenofovir. His daily pill count will increase to 11 pills, taken at three different times of the day. But that's not all. The price of second-line therapy costs $\$ 1,285$ per year - nearly three and a half times the cost of average first line therapy (\$363 per year). The higher costs will, naturally, limit the total numbers of patients who can be treated. Darder and Boulle note that the difference in price exists largely due to the lack of generic competition in the second-line market. See M Darder \& A Boulle 'Second-line ARV Treatment: Unaffordable Luxury?' Médecins sans Frontières (7 November 2004), $<$ http://www.msf.org $>$. The Clinton Foundation and MSF are in the process of negotiating access to expensive second line drugs under patent. Due to efforts by MSF, the Student Global AIDS Campaign and other advocates, a new formulation of an expensive second-line ARV, Kaletra (manufactured by Abbott), recently became available in just three countries in Africa (Cameroon, Nigeria and South Africa). While the price remains high, this new formulation is heat-resistant and does not require refrigeration. Nor does the patient need to take the 
Far-Manguinhos further serves as a visible reminder that health is a public good. In the current international climate, the neo-liberal discourse of markets, free trade and privatisation dominate politics. Capitalism's privatisation of the public good induces a powerful form of amnesia: we forget that France did not permit pharmaceutical patents until 1959; that Germany followed suit in 1969 and that other industrialised and developed nations have only done so quite recently (Japan (1976), Switzerland (1977), Italy (1978), Sweden (1978), and Spain (1992)). ${ }^{48}$ Brazil's stance harkens back to a time — not long past — when medicinal drugs were simply not patentable.

Brazil's retreat on patents then must be viewed as strategic. The government's ability to take the long view and make investments in FarManguinhos that may never result in the direct diminution of ARV costs demonstrates that this retreat has not, as yet, displaced a deeper commitment to political solidarity. As Brazil's Ministry of Health noted in the following one-page advertisement in The New York Times:

AIDS is not a business. The Brazilian Ministry of Health distributes the anti-AIDS cocktail free in Brazil to anyone who needs it. . . Local manufacturing of many of the drugs used in the anti-AIDS cocktail is not a declaration of war against the drugs industry. It is simply a fight for life. ${ }^{49}$

\section{(d) South to South: sourcing APIS and importing generics in the face of TRIPS compliance}

We have noted with some concern that Brazil's National AIDS Programme remains quite dependent upon countries with the capacity - namely India, China and South Korea - and the willingness to provide generics or the APIs required for their production. The fragility of the Brazilian pharmaceutical industry and an international climate somewhat hostile to the production of generic versions of drugs under patent means that Brazil's ARV programme will remain vulnerable.

medicine with food, thus facilitating both patient adherence and storage. Kaletra remains unavailable to patients in Asia, Latin America and all other African countries. UN Integrated Regional Information Networks (UN-IRIN) 'Africa: New-Version Kaletra Victory for MSF' (26 July 2006).

48 For a brief history of patents for medicinal drugs, as well as the arguments for and against patents for pharmaceutical substances or methods of treatments, see B Loft \& M Heywood 'Patents on Drugs: Manufacturing Scarcity or Advancing Health' (2002) 30 Journal of Law, Medicine \& Ethics 621.

49 The New York Times (18 June 2001). Then-President of Brazil, Fernando Henrique Cardoso, used a similar platform to underscore his country's commitment to providing access to ARVs for all HIV-infected Brazilians. In a speech in Washington, DC in 2001, Cardoso stated: 'Brazil has raised this banner because it is a cause that has to do with the very survival of some countries, especially the poor ones This is a political and moral issue that has to be viewed realistically and can't be solved just by the market.' See M Petersen \& L Rohter 'Maker Agrees to Cut Price of Two AIDS Drugs in Brazil' The New York Times (31 March 2001). 
One positive sign for Brazil's current ARV strategy, and that of other countries, is the manner in which India agreed to become TRIPS compliant. India had bought itself a decade of TRIPS non-compliance with promises to bring its patent law into line with international norms in 2005. In March 2005, the Indian Parliament passed the Patents (Amendment) Act, 2005. The earlier Act made provision for 'only limited term process patent protection for inventions relating to food, drugs and medicines. ${ }^{50}$ The Patents Act 2005 deletion of this section and new language that extends patent protection to 20 years of protection for all categories of inventions satisfies the most basic requirements of TRIPS compliance.

Such compliance could have ended Brazil's access to India's market in generics and APIs. However, as several authors note, s 92A(1) of the Patents (Amendment) Act actually expands the scope of issuance of compulsory licences for the manufacture and the export of 'patented pharmaceutical products'. 51 More importantly for Brazil, s 92A(1) enables countries with insufficient production capacity to manufacture their own pharmaceutical products under compulsory licensing and to import such products if it simply provides the required 'notification of need' for the drug in terms of TRIPS and the Doha Agreement. ${ }^{52}$

India's expanded compulsory licensing provisions permit its generics' industry to produce the drugs required for its own domestic consumption and secures, for the time being, the continued access of other developing countries to its store of generics. Whether the Indian government has struck an acceptable balance between demands for TRIPS-compliant intellectual property protection and public health requirements remains to be seen. ${ }^{53}$ One obvious virtue of the Indian law's language is that it does not require the importing country to issue a compulsory license. At the level of rhetoric, therefore, Brazil can maintain its claim that it has yet to abrogate its international commitments with respect to patent protection. Such a claim remains an important tool in negotiations with multinational pharmaceutical companies and with countries such as the United States that press for greater patent protection than TRIPS in fact requires. At the level of lived experience, the continued access to India's generics indicates that Brazil should be able to continue to exploit the

50 Ministry of Law and Justice (India) 'The Patents (Amendment) Act 2005, No. 15 of 2005 The Gazette of India (5 April 2005), < http://www.patentoffice.nic.in/ipr/patent/patent 2005.pdf $>$; < http://www.indialawinfo.com $>$.

51 Ibid.

52 To date, Brazil has not exercised its compulsory licensing capability. It has only threatened to do so. No country, save Canada, has yet issued a compulsory license for the generic production of a patented drug. Compulsory licensing enables a government to permit a third party to produce a patented product or to use a patented process without consent of the owner of the patent. See Mercurio (note 41 above) 249.

53 Ministry of Law and Justice (India) 'The Patents (Amendment) Act 2005, No. 15 of 2005 The Gazette of India (5 April 2005), < http://www.patentoffice.nic.in/ipr/patent/patent_2005.pdf >. 
differential pricing structure that multinationals have offered for the sale of ARVs in developing countries.

\section{Historical AND legal conditions that make Possible a South AFRICAN POLICY OF UNIVERSAL, FREE ARV THERAPY FOR THE GREATEST NUMBER AT THE LOWEST COST}

In South Africa, the apposite historical and legal conditions for a universal rollout share a family resemblance to those that obtain in Brazil. South Africa experienced its velvet revolution six years after Brazil - in 1994. As with the end of authoritarian rule in Brazil, the end of apartheid in South Africa meant the introduction of such basic democratic considerations as fairness, equitability, accountability and transparency into the domain of commercial relations with the state. Brazil's Tender Law has its equivalents in such recent South African legislation as the Public Finance Management Act, ${ }^{54}$ the Local Government Municipal Systems Act ${ }^{55}$ and the Preferential Procurement Policy Framework Act. ${ }^{56}$ Both countries must contend with the demands of realising the democratic ends of their new constitutional democracies against the backdrop of the world's two highest Gini coefficients.

Like Brazil, South Africa possesses a sophisticated civil society that has championed the rights of people living with HIV/AIDS. Unlike Brazil, South Africa's government has neither pressed a progressive political agenda with regard to HIV/AIDS, nor implemented the multiple dimensional policy framework - from industrial policy, to drug procurement to human resource development - required for an effective national ARV rollout. Indeed, despite the lip-service paid to effecting a universal rollout, the current government appears to be in the thrall of rather outré theories that either deny the causality of HIV with respect to AIDS or the efficacy of ARVs with respect to the treatment of AIDS. ${ }^{57}$ Moreover, in Brazil, we have seen that the deleterious effects of the liberalisation of trade on the pharmaceutical industry have been tempered by an industrial policy designed to ensure that the Brazilian state is able to afford a sustainable ARV programme. No such counterweight to liberalisation as yet obtains in South Africa. Industrial policy has been driven largely by the desire to attract foreign direct

\footnotetext{
54 Act 1 of 1999.

55 Act 32 of 2000 .

56 Act 5 of 2000 .

57 See 'State Condones AIDS Herbs' Business Day (14 February 2006); S Friedman 'On HIV AIDS, Government Still Speaks with a Forked Tongue' Business Day (6 February 2006).
} 
investment. ${ }^{58}$ Assuming that this neo-liberal framework will continue to shape the political landscape, we offer an argument that demonstrates how extant industrial policies in South Africa can be profitably exploited to promote the development of a sustainable ARV treatment programme.

\section{(a) The legal environment}

\section{(i) A justiciable constitutional right to health}

The South African Constitution contains one of the few genuinely justiciable constitutional rights to health care. ${ }^{59}$ The content of that right - although it remains contested - has been fleshed out by the courts in a number of important cases. ${ }^{60}$ For our limited purposes, we can extract the following principles from this complex body of jurisprudence:

58 Over ten years ago, the new government forged a specific social contract with the South African people. The Reconstruction and Development Programme ('RDP') - an integrated and sustainable poverty alleviation programme for the nation - viewed poverty as the greatest threat to the new South Africa. However, as Southall and others note, the highly progressive RDP was largely superseded by the neo-liberal Growth, Employment and Redistribution strategy ('GEAR'). GEAR shifted government's approach from direct expenditure on social entitlements for such basic goods as health, housing, water, food and employment to a more indirect, market-based approach. See J Daniel, A Habib \& R Southall (eds) State of the Nation: South Africa 2003-2004 (2003) 55; L Schlemmer 'Can South Africa's Democracy Survive its History and Political Culture?' Helen Suzman Foundation Survey (April 2002).

59 See s 27(1) and s 27(3): '(1) Everyone has the right to have access to - (a) health care services, including reproductive health care; (b) sufficient food and water; and (c) social security, including, if they are unable to support themselves and their dependants, appropriate social assistance. (2) The state must take reasonable legislative and other measures, within its available resources, to achieve the progressive realisation of each of these rights. (3) No one may be refused emergency medical treatment'. Section 27 is formulated differently from the right to health at an international level. The Constitution splits that right in two. The right to a healthy condition has been included within the environmental right: s 24(a). The rights of access to health care and emergency medical treatment are found in s 27(1) and (3). See D Bilchitz 'Health' in S Woolman, T Roux, J Klaaren, A Stein, M Chaskalson \& M Bishop (eds) Constitutional Law of South Africa (2nd Edition, OS, December 2005) Chapter 56A. As David Bilchitz also notes: 'The Interim Constitution ... did not enshrine any of the traditional socioeconomic rights and thus there was no right to health expressly included in it. The only aspect of health protected within that Constitution was contained within the environmental right which guaranteed each person the right to 'an environment which is not detrimental to his or her health or well-being.' Put slightly differently, the Interim Constitution guaranteed a right to a healthy environment - without any guarantee that one would be entitled to the resources or services necessary to stay healthy. Ibid. For more on the right to a healthy environment, see $\mathrm{M}$ van der Linde and E Basson 'Environment' in Woolman et al (eds) Constitutional Law of South Africa (2nd Edition, OS, December 2004) Chapter 50.

60 The leading Constitutional Court cases are: Soobramoney v Minister of Health, Kwazulu-Natal 1998 (1) SA 765 (CC); Government of the Republic of South Africa v Grootboom 2001 (1) SA 46 (CC); Minister of Health v Treatment Action Campaign (2) 2002 (5) SA 721 (CC) ('TAC'); Khosa v Minister of Social Development 2004 (6) SA 505 (CC). For a comprehensive analysis and critique of this body of jurisprudence, see D Bilchitz (2001) 'Giving Socio-Economic Rights Teeth: The Minimum Core and Its Importance' (2002) 119 SALJ 484; D Bilchitz 'Towards a Reasonable Approach to the Minimum Core: Laying the Foundations for Future Socio-Economic Rights Jurisprudence' (2003) 19 SAJHR ; T Roux 'Legitimating Transformation: Political Resource Allocation in the South African Constitutional Court' (2003) 4 Democratization 10 (discusses the different standards of review adopted by the Court in 
- The right to health-care services does not, generally speaking, embrace an entitlement to the immediate award of a remedy in the event of a breach; ${ }^{61}$

- The right simply requires the state to progressively realise the access to health care services for individual members of the polity and to do so within 'available resources'; 62

- Whether the state has discharged its duty to progressively realise the right will be evaluated by the courts in terms of the 'reasonableness' of the plan; ${ }^{63}$

- To be found reasonable, a comprehensive and coordinated programme to realise the right to health: (1) must ensure that 'the appropriate financial and human resources are available'; (2) 'must be capable of facilitating the realisation of the right'; (3) must be reasonable 'both in their conception and their implementation'; (4) must attend to 'crises'; (5) must not exclude 'a significant segment' of the affected population; and (6) must 'respond to the urgent needs of those in desperate situations. $^{64}$

How these principles might play out with respect to the provision of ARVs through a state-funded programme can be discerned in two cases. In Van Biljon $v$ Minister of Correctional Services, four prisoners

socio-economic rights cases). See also S Liebenberg 'The Interpretation of Socio-Economic Rights' in S Woolman et al (eds) Constitutional Law of South Africa (2nd Edition, OS, 2003) Chapter 33; S Liebenberg 'The Value of Human Dignity in Interpreting Socio-Economic Rights' (2005) 21 SAJHR 22; M Pieterse 'Coming to Terms with the Judicial Enforcement of Socio-Economic Rights' (2004) 20 SAJHR 383; D Moellendorf (1998) 'Reasoning About Resources: Soobramoney and the Future of Socio-Economic Rights Claims' (1998) 14 SAJHR 327; M Wesson 'Grootboom and Beyond: Reassessing the Socio-Economic Rights Jurisprudence of the South African Constitutional Court' (2004) 20 SAJHR 284. For an account that approves of the court's deferential approach, see CR Sunstein 'Social and Economic Rights? Lessons from South Africa' (2001) 11 Constitutional Forum 123 (Defending the Court's administrative law model of socio-economic rights.)

61 Soobramoney (note 60 above); Grootboom (note 60 above); TAC (note 60 above).

62 See Soobramoney (ibid). See also $R v$ Cambridge Health Authority, ex Parte B [1995] 2 All ER 129,137 (CA)('I have no doubt that in a perfect world any treatment which a patient or a patient's family sought would be provided if doctors were willing to give it, no matter how much it cost, particularly when a life was potentially at stake. It would however, in my view, be shutting one's eyes to the real world if the Court were to proceed on the basis that we do live in such a world. It is common knowledge that health authorities of all kinds are constantly pressed to make ends meet. They cannot pay their nurses as much as they would like; they cannot provide the treatments they would like; they cannot purchase all the extremely expensive medical equipment they would like; they cannot carry out all the research they would like; they cannot build all the hospitals and specialist units they would like. Difficult and agonising judgments have to be made as to how a limited budget is best allocated to the maximum advantage of the maximum number of patients.')

63 See Khosa (note 60 above) para 43: 'In determining reasonableness, context is all-important. There is no closed list of factors involved in the reasonableness enquiry and the relevance of various factors will be determined on a case by case basis depending on the particular facts and circumstances in question.'

64 See Grootboom (note 60 above) paras 39-46, 52, 53, 63-69, 74, 83. 
determined to be HIV positive sought orders declaring that, under s 35(2)(e), they had the "the right . . . to . . . the provision, at State expense, of adequate . . medical treatment. ${ }^{65}$ The High Court held that the two prisoners who had been prescribed a combination of $\mathrm{AZT}^{66}$ and ddl by medical practitioners were entitled to provision of that cocktail at state expense, but that the two prisoners who had not as yet been prescribed either antiviral mono-therapy or antiviral dual therapy were not entitled to provision of any treatment at state expense. Although not decided under s 27, but under the health care provision for prisoners under s 35(2), Van Biljon stands for the proposition that socio-economic rights do not entitle individuals to specific remedies unless the state has already committed itself to the provision of specific benefits. Thus, in Van Biljon, only the first two applicants are provided with ARVs because only the first two applicants could form a legitimate expectation that the state would provide them with such treatment.

Similarly, in Minister of Health $v$ Treatment Action Campaign ('TAC'), the applicants took issue with the South African government's policy toward the provision of nevirapine, an antiretroviral drug that reduces the likelihood of HIV transmission from mother to child by one-half to two-thirds. ${ }^{67}$ Despite the fact that the manufacturers of nevirapine had offered to make the drug available to the South African government free of charge for a period of five years in order to reduce the risk of the vertical transmission of HIV, only a fraction of the hundreds of thousands of pregnant women infected with HIV had access to nevirapine at an equally small number of research and training sites throughout the country. ${ }^{68}$ The Constitutional Court held that, in terms of s 27, the government's decision to confine nevirapine to a limited number of research and training sites was manifestly not reasonable. ${ }^{69}$ The $T A C$ Court found that a comprehensive and coordinated programme of nevirapine and breast milk substitutes could substantially reduce the risk

651997 (4) SA 441 (C). All four had CD4 counts of less than 400/ml. All four therefore satisfied generally accepted criteria for antiretroviral treatment at the time. Two of the prisoners had already been prescribed appropriate antiretrovirals by medical practitioners. The other two prisoners had not had any antiretroviral treatment prescribed by the state.

66 Azidothymidine or zidovudine (commonly known as AZT or ZDV) was the first antiretroviral drug approved for the treatment of HIV. It is also sold under the brand names of Retrovir and Retrovis. See Medline Plus, an electronic service of the US National Institutes of Health and the US National Library of Medicine, < http://www.nlm.nih.gov/medlineplus/druginfo/uspdi/ 202602.html>.

67 See UNAIDS 'Mother to Child Transmission of HIV' UNAIDS Technical Update (October 1998). In the absence of such treatment, the probability of mother to child transmission in developing countries is estimated by UNAIDS to be 25 to 35 per cent. The virus can be transmitted from the mother to the child during pregnancy, labour, delivery and through breastfeeding. UNAIDS 'Mother to Child Transmission of HIV' UNAIDS Technical Update (October 1998). See TAC (note 60 above)

68 See $T A C$ (note 60 above) para 16.

69 Ibid. 
of vertical transmission of HIV without placing a significant burden on the fiscus. Accordingly, the Constitutional Court issued a mandamus that required the government to extend the provision of nevirapine beyond the current sites and ordered the government to provide the requisite testing and counseling services needed to make effective use of nevirapine. $^{70}$

$T A C$ may seem like an easy case whose reach is rather limited. That is, $T A C$ could be viewed as simply extending a benefit to a class of person who might have already formed a legitimate expectation of an entitlement to that benefit. But $T A C$ required somewhat more of the Court. It required the Court to assess whether the state possessed the available resources necessary to make a comprehensive and coordinated programme of universal nevirapine provision possible. The TAC Court found that the state did.

This finding has an important bearing on our assessment of current government policy regarding the rollout of ARVs. What we argue, in the analysis that follows, is that the government has the necessary resources to create a low-cost coordinated, comprehensive and universal ARV treatment programme. Not only does TRIPS permit the importation of or the local production of ARVs (including APIs) necessary for affordable treatment, South Africa possesses the nascent industrial capacity necessary to produce inexpensive generics. What South Africa can do to exploit such capacity - in terms of law and industrial policy is discussed below. Failure to properly utilise such readily available tools - in the context of 3.5 million South African deaths by 2010 - may well constitute a failure to provide the comprehensive and coordinated

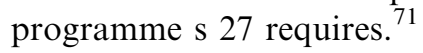

\section{(ii) Intellectual property rights}

The Constitution does not constitute a meaningful constraint on the access to essential medicines for the government's HIV/AIDS programme. Intellectual property rights ('IPR') do.

TRIPS and our own Patent Amendment Act have certainly tightened the current intellectual property rights regime. However, both documents contain significant flexibility with respect to securing access to medicines deemed essential to meet public health objectives for developing countries. Moreover, recent litigation in the High Court, and complaints before the Competition Commission and Competition Tribunal, demonstrate that the South African government has the necessary space to

70 The TAC's victory in this matter demonstrated the success of targeted litigation and civil society mobilisation in realising the over-arching goal of universal access to ARV treatment for South Africans infected with HIV/AIDS.

71 See Dorrington (note 2 above); UNAIDS Report on the Global AIDS Epidemic (2004). 
produce a socio-industrial policy that could - under the correct macroeconomic conditions - support a sustainable ART programme.

\section{(aa) International Intellectual Property Regime: WTO and TRIPS}

The World Trade Organization (WTO) governs international trade in goods, services, and intellectual property (IP). ${ }^{72}$ The WTO was officially established in 1994, supplanting its forerunner, the General Agreement on Tariffs and Trade (GATT). ${ }^{73}$ Under GATT, IP was largely unregulated. $^{74}$

Even prior to the WTO's creation, the United States and other industrialised countries began to link IP protection to international trade. ${ }^{75}$ The growing importance of IP on the international trade agenda led to the Agreement on Trade-Related Aspects of Intellectual Property Rights (TRIPS). TRIPS requires WTO members to set forth minimum standards by which they will enforce intellectual property rights. Its ostensible purpose is the harmonisation of patent protection within the strictures of the multilateral trading system. ${ }^{76}$

72 The 144 WTO member countries represent 90 per cent of world trade. The WTO has a staff of roughly 560 , headed by a director general, with a budget of 143 million Swiss francs. See WTO Agreements and Public Health: A Joint Study by the WHO and WTO Secretariat (2002) 28. For a robust discussion of Africa's position vis-à-vis the evolving world trading system, see TA Oyejide \& W Lyakurwa (eds) Africa and the World Trading System Volume I: Selected Issues of the Doha Agenda (2005).

73 GATT was similarly conceived in 1947 to 'remove or diminish barriers which impede the flow of international trade and to encourage by all available means the expansion of commerce.' Twenty-three members were signatories to the international trade agreement in October 1947. They agreed to extend the principle of most-favoured nation, whereby a party that accords any advantage, favour, privilege or immunity to any product originating in or destined for any other country must extend the same benefit to the life product originating in or destined for the territories of all other contracting parties. In such bilateral agreements, a minimum of two countries would benefit. However, a multiplier effect of rights and obligations would be passed on to other countries. See M Tomz, J Goldstein \& D Rivers 'Membership Has Its Privileges: The Impact of GATT on International Trade', Paper presented at the Annual Meeting of the American Political Science Association (28 August 2003), < http://www.stanford.edu/7Etomz working/working.shtml $>$.

74 Under GATT, patent protection and regulation was handled by the World Intellectual Property Organisation (WIPO). WIPO was, prior to 1994, largely regarded as impotent with respect to patent enforcement. See B Mercurio (note 41 above) 215.

75 The US made aggressive use of its US Court of International Trade to litigate against countries allegedly practicing unfair trade. See Mercurio (note 41 above) 216-217.

76 WTO Agreements and Public Health (note 72 above) 38. The WTO and WIPO remain the only two international agencies charged with patent protection. Most industrialised countries became TRIPS compliant in the mid-1990s, with the developing countries doing so by the year 2000. The least developed countries (LDCs) have until 2016 to comply with some aspects of TRIPS. See DFID Health Systems Resource Centre 'Access to Medicines in Under-Served Markets: What are the Implications of Changes in Intellectual Property Rights, Trade and Drug Registration Policy?' (September 2004), < http://www.eldis.org/healthsystems/access/ index.htm > 
Because prices on pharmaceutical products will generally rise when patent protection is introduced or increased, ${ }^{77}$ TRIPS has been the focus of efforts to negotiate the inevitable conflict between IP protection and the promotion of access to life-saving essential medicines in developing countries. ${ }^{78}$ The WTO process to address the tension between providing pills and protecting patents began to gain traction during the Doha Round in 2001. The resulting Doha Declaration confirmed that TRIPS should be interpreted in such a way as to support WTO members' rights to protect public health and to promote access to medicines for all. Most importantly, the Declaration reaffirmed that art 31 of TRIPS allows all WTO members to grant compulsory licenses in order to protect public health. ${ }^{79}$ Compulsory licensing enables a government to permit a third party to produce a patented product or to use a patented process without consent of the owner of the patent. ${ }^{80}$ With the primacy of public health affirmed, Doha was viewed as a tangible win for developing countries and heralded as a major step forward in the global campaign for access to essential medicines. ${ }^{81}$

In spite of this apparent progress, fundamental conflicts between the political imperatives of developed countries and the developing countries remained unresolved. Paragraph 6 of the Declaration called for the finding of 'an expeditious solution to the problem of the difficulties that WTO members with insufficient or no manufacturing capacities in the pharmaceutical sector could face in making effective use of compulsory

77 This increase is generally related to the following factors: the degree of competitiveness of the local pharmaceutical market prior to patent protection; the larger the market share of copied drugs; and the more price inelastic the demand for medicines. See E Teljeur 'Intellectual Property Rights in South Africa: An Economic Review of Policy and Impact' The Edge Institute $(2000)<$ http://www.the-edge.org.za/publications.htm $>$.

78 Critics of TRIPS assert that there has not, as yet, been a satisfactory solution to ensure the supply of sustainable medicines at low cost for lower and middle income countries even as health threats such as malaria, tuberculosis and HIV/AIDS have increased dramatically. By 2001, the WHO's World Health Report 2001 cited the leading causes of illness and death in Africa, Asia and South America as HIV/AIDS, malaria, TB and respiratory infections. See WHO The World Health Report 2001 (2000). Despite this increase in morbidity and mortality rates, international IP rules have tightened over this same period of time. As a result, MSF estimates that only 12 per cent of the six million people globally who require treatment for these three diseases are able to access such treatment. See IRIN News (UN-OCHA Integrated Regional Information Networks) 'Lazarus Drug: ARVs in the Treatment Era' (September 2005) < http://www.irinnews.org $>$.

79 See F Abbott 'The WTO Medicines Decision: World Pharmaceutical Trade and the Protection of Public Health' (2005) 99 (2) American J of Int Law 317.

80 Most countries afford provision for compulsory licensing in their national legislation. See WTO Agreements and Public Health (note 72 above) 45.

81 The Doha Round of negotiations was the first time that international health and development objectives of the developing world were debated at every level of WTO governance. See E t'Hoen 'TRIPS, Pharmaceutical Patents and Access to Essential Medicines: Seattle, Doha and Beyond' (2003) International AIDS Economics Network, < http://www.iaen.org/papers/ > . 
licensing under the TRIPS Agreement and to report to the General Council before the end of 2002. ${ }^{82}$

After two years of thorny negotiations, a resolution was achieved. All members agreed to use the procedures outlined in art 31(f) to implement para 6 , ie, to exercise use of compulsory licensing. However, many NGOs were dismayed with the final agreement, indicating that it was too complex, bureaucratic and slow to be implemented by developing countries in practice. On 30 August 2003, the General Council issued a decision with regard to the implementation of para $6 .{ }^{83}$ The General Council held that an interim waiver would remain in effect until an Amendment to TRIPS could be formulated. No such amendment has been forthcoming.

Whether Doha will produce significant benefits for the developing world remains to be seen. Only Canada, for example, has issued a compulsory license to gain access to medicines. Moreover, after Doha, the US and other developed nations entered into a series of free trade agreements (FTAs) with developing countries that further restricted the flexibilities under TRIPS with respect to pharmaceutical products. The terms vary but the theme remains the same: the agreements limit exclusions from or exceptions to patents and patentability. ${ }^{84}$ Developing countries, anxious to benefit from FTAs, began to relinquish the flexibilities TRIPS had secured with regard to accessing essential medicines. ${ }^{85}$ Whether TRIPS will permit developing countries to take advantage of its flexibilities will depend, to a significant degree, on the willingness of individual nations - such as Brazil, China, India and

82 Implementation of Paragraph 6 of the Doha Declaration on the TRIPS Agreement and Public Health, Decision of the General Council of 30 August 2003, < http://www.wto.org >

83 See Mercurio (note 41 above); Abbott (note 79 above) 317; t'hoen (note 81 above) 79.

84 See Abbott (note 79 above) 349 - 357. (The specific provisions range from requiring the grant of patents for "new uses" of known compounds, to extending patent terms under particular conditions, to preventing parallel importation and to limiting the criteria by which compulsory licensing can be used.)

85 Frederick Abbott identifies the following trends in IP:

'The Pharma companies are asking for and obtaining stronger protection for patents and regulatory data, and the reduction or elimination of price controls. . strong monopolies and reduced regulatory flexibility threaten to exacerbate the already alarming disparity in medicinal treatment between rich and poor ... The uncertainty created by the intellectual property chapters and the potential impact on developing country public health and intellectual property authorities should not be underestimated. Few governments wish to become engaged in a trade dispute with the United States and most lean toward erring on the side of caution.'

Abbott (note 79 above) 353. Put another way, while TRIPS affords genuine flexibility in gaining access to the medicines necessary to meet public health crises in developing countries, these bilateral agreements erode such flexibility by requiring many developing countries to promulgate 'TRIPS plus legislation'. Such legislation often extends patent life beyond two decades and places severe restrictions on the use of compulsory licenses and other exceptions that would allow for the introduction of generic medicines. See t'Hoen (note 81 above). 
South Africa - to resist political pressure from the developed world for additional IP concessions in FTAs. ${ }^{86}$

(bb) Medicines and Related Substances Control Amendment Act and the Patent Amendment Act

South Africa's main muscle for accessing low cost medicines for its citizens is the Medicines and Related Substances Control Amendment Act. ${ }^{87}$ The Medicines Act contains provisions for the transparent pricing of medicines, the parallel importation of patented drugs, and the generic substitution of patented medicines under certain conditions.

Prior to the Medicines Act's implementation, the Pharmaceutical Manufacturers' Association of South Africa filed suit on behalf of 39 drug companies to prevent the law from taking effect. ${ }^{88}$ The applicants contended that the Medicines Act contravened both the Constitution and TRIPS. ${ }^{89}$ The gravamen of their complaint was that the Act granted the Minister of Health unlimited discretion to ignore the country's patent laws.

Shortly after the trial began in March 2001, it became clear that the section of the Medicines Act at the centre of the dispute was modeled on a draft legal text prepared by the WIPO Committee of Experts. Given WIPO's involvement, and WIPO's role in TRIPS enforcement, it became impossible for the drug companies to argue that the Medicines Act violated TRIPS. ${ }^{90}$ In April 2001, due to their weak legal position, and the

86 See Abbott (note 79 above). A Working Group on Transfer of Technology was established in Doha. It examined the relationship between trade and the transfer of technology from developed countries to developing countries, and ways to increase the flow of technology to developing countries. WTO ministers decided in Doha to establish a working group to examine the issue, and also any possible recommendations on steps that might be taken within the WTO to increase flows of technology. A group of developing countries has suggested focusing on WTO provisions related to technology transfer with a view towards making them meaningful.

87 Act 90 of 1997 ('Medicines Act').

88 See Government of the Republic of South Africa (Dept of Health) 'Briefing Document: Defending the Medicines Control Amendment Act' 2 March 2001.

The drug companies are contending that the courts should strike down numerous sections of the Medicines Act because they contradict the Constitution of South Africa in various ways. These include: the extent of the powers conferred on the Minister of Health; deprivation of intellectual property in a manner that amounts to expropriation without compensation; various forms of discrimination against sections of pharmaceutical industry; restriction of freedom of trade; failure to comply with legislative procedures set down in the Constitution; the applicants also argue that some of the provisions are in conflict with the TRIPS Agreement which is binding on South Africa. See also H Cooper, R Zimmerman \& L McGinley 'Patents Pending: AIDS Epidemic Traps Drug Firms in a Vise: Treatment vs. Profits - Suit in South Africa Seeks to Block Generic Copies; US Reverses its Policy - Activists Warn Mr Papovich' The Wall Street Journal (2 March 2001). (Pharmaceutical firms filed suit against the Medicines Act because they feared other countries might follow a similar path.)

89 Case No 4183/98 (Witwatersrand High Court, filed 18 February 1998).

90 See t'Hoen (note 81 above) 79 . 
strong international support for South Africa's attempt to provide cheaper medicines to meet a public health epidemic, the companies dropped the suit. ${ }^{91}$

While the suit ultimately set no legal precedent, the outcome tilted the balance of power back, ever so slightly, toward developing countries. At a minimum, multinational drug companies recognized that they had very little to gain by their aggressive enforcement of publicly unpopular legal positions.

\section{(cc) The Competition Commission, the Competition Tribunal and voluntary licenses}

The withdrawal of the suit did not end the legal wrangling. During the litigation, the drug companies acknowledged that they had offered the South African government reduced prices on anti-AIDS medicines. It

91 The story behind the suit exemplifies the power politics at its most raw and rarefied. The South African government argued that its legislation conformed to TRIPS, relying on the flexibilities available in Paragraph 6. A spokeswoman for the Ministry of Health stated that equal access to health care in South Africa was constitutionally protected and that the access problem was so deep it required a 'major structural intervention.' The US subsequently denied Pretoria's request in 1998 for additional benefits for health care products under the Generalized System of Preferences ('GSP'). The GSP allows developing countries to import products with duties set at reduced rates. US Representative Rodney Frelinghuysen made a statement on behalf of the drug companies in his state, New Jersey, declaring that he was attaching an amendment to South African aid legislation that would hold up payments until the US government demonstrated it would pressure South Africa on the Medicines and Related Substances Control Amendment Act. The European Commission and US government joined together to press South Africa to repeal the Act. In April 1999, the office of the US Trade Representative added South Africa to its annual Watch List, citing that the Amendment Act could potentially abrogate patent rights. The US threatened to withhold trade benefits and impose trade sanctions.

The contest was, however, not at all one-sided. Highly-organised civil society movements rallied behind the South African government. A coalition that included religious groups, women's groups, trade unionists, AIDS activist NGOs such as Act Up, Health Gap Coalition, TAC, ALP, stalwart organisations with global networks such as Médecins sans Frontières (MSF) and Oxfam, and well respected leaders such as Nelson Mandela and Kofi Annan pressed the pharmaceutical companies to drop their suit. Eventually even the European Parliament demanded that the companies withdraw their complaint. See t'Hoen (note 81 above); R Petchesky Global Prescriptions Gendering Health and Human Rights (2003) 76-108. On the global stage, from 1997 to 2002, a range of forces conspired to bring about reductions in global prices for anti-AIDS drugs. The precise unfolding of events will not be reconstituted here, save for four key markers in which South Africa plays a role. In May of 2000, multinational pharmaceutical companies announced price reductions for AIDS treatment from US\$15,000 to \$ 700. Cipla of India then offered the same drugs for \$300. In April 2001, the South African court case involving the 39 pharmaceutical companies was dropped, and in November of 2001 at the 4th WTO Ministerial Conference in Doha, Qatar, the 'Declaration on TRIPS and Public Health' was adopted. At that time, the South African government's leadership on this issue was significant in creating opportunities for developing countries to access affordable essential medicines. The Declaration affirmed the right of governments to take the necessary measures to protect public health, giving primacy to public health, including the use of compulsory licensing and parallel import to overcome excessive drug prices. For more on this topic, see t'Hoen (note 81 above); MSF 'AIDS Treatment Still Reaching but a Fraction of All Those in Need' (19 April 2002); G Velásquez 'Essential Drugs and Medicines Policy' Geneva: World Health Organization (October 2002). 
was an offer that the South African government had concealed and, evidently, failed to leverage. ${ }^{92}$ This apparent failure on the part of the South African government was particularly galling given that it had continued to claim - during the litigation - that the high prices of ART prohibited a national AIDS treatment programme.

By 2002, with the price of ARV drugs still unaffordable for the majority of South Africans, the Treatment Action Campaign (TAC) lodged a complaint with the Competition Tribunal which asserted that a proposed merger between Glaxo Wellcome and Smithkline Beecham would so increase the new company's South African market share as to inevitably lead to monopoly-like prices for a significant number of ARVs. ${ }^{93}$ The Competition Tribunal rejected this contention. However, the Tribunal's concerns - if not TAC's - were allayed by the agreement of the merging parties to issue voluntary licenses for several drugs: antiemetic Kytril; anti-viral Famciclovir; and antibiotics Polysporin, Cicatrin and Neosporin. ${ }^{94}$

Although TAC and ALP lost this particular battle, they recorded a meaningful victory in Hazel Tau. ${ }^{95}$ In the Hazel Tau settlement agreements with Boehringer Ingelheim and GlaxoSmithKline (GSK), TAC and ALP secured new voluntary licensing agreements - and extended already existing voluntary licenses — from GSK and Boehringer Ingelheim. These voluntary licenses agreed to the production and sale of nevirapine, AZT and lamivudine (commonly known as 3TC) within South Africa and for export to 47 countries in Africa for a royalty of no more than five per cent of net sales. ${ }^{96}$ By signing these voluntary

92 See Petchesky (note 91 above) 90 .

93 Legal representation for the TAC was provided by the AIDS Law Project (ALP). The goal of the TAC and ALP was to ensure that affordable medicines would be made available through the reduction of excessively high prices charged by two pharmaceutical companies for antiretroviral medicines. See Competition Commission Media Release No 28 of 2002 (28 November 2002), <http://www.tac.org.za > .

94 See Glaxo Wellcome and Smithkline Beecham v Competition Commission Case No 58/AM/May (28 July 2000).

95 Hazel Tau Competition Commission Case No 2002 Sep 226.

96 See Settlement Agreement entered into and between the twelve complainants to the Competition Commission in South Africa in terms of the Competition Act, under and in connection with Case No 2002 September 26, and, GlaxoSmithKline South Africa (Pty) Ltd, Glaxo Group Limited and the Wellcome Foundation Limited; and Settlement Agreement between the Generic Anti-Retroviral Procurement Project (incorporated under Section 21 of the Companies Act, No. 61 of 1973) and the TAC Treatment Project and Boehringer Ingelheim Pharmaceuticals Inc. It is important to note that Aspen Pharmacare had already entered into voluntary licensing agreements with both GlaxoSmithKline and Boehringer Ingelheim prior to the initiation of this round of litigation. Furthermore, those voluntary licensing agreements do not require the payment of any royalty to GlaxoSmithKline or Boehringer Ingelheim. It is also important to note that such no-royalty, voluntary licenses evolved over time. What began as contracts that granted limited immunity from suits from patent infringement grew into selective license agreements. These selective license agreements became voluntary license agreements with a five per cent royalty. After almost a decade of negotiation and cooperation, these agreements now generally contain some extraordinary 
licenses, both GSK and Boehringer Ingelheim had agreed not to seek enforcement of these patents. ${ }^{97}$ As we shall see, these agreements demonstrate that voluntary licenses can - in the right environment - be profitably exploited in the service of a free, universal ART programme for the treatment of HIV/AIDS. ${ }^{98}$

\section{(dd) Interim conclusions about South Africa's IP regime}

South Africa has, by many accounts, a 'state of the art' TRIPS-compliant intellectual property regime. ${ }^{99}$ And yet, despite concerns that a strong IP regime retards the ability of governments in the developing countries to provide essential medicines, we have seen evidence that South Africa's IP regime has sufficient flexibility to allow both public officials and private

features - especially from the vantage point of those who require access to essential medicines. The agreements contain, as a rule, 0 per cent royalty charges, backward technology transfers, and assistance with respect to both the manufacture and the distribution of the pharmaceutical. See also GSK (GlaxoSmithKline) Corporate Social Responsibility Report 2005 (2005) GlaxoSmithKline, which has signed seven voluntary licensing agreements for ARVs in Africa (five in South Africa and two in Kenya) outlines the pharmaceutical company's perspective on voluntary versus compulsory licenses as follows:

Voluntary licences (VL) enable local manufacturers to produce and sell generic versions of our products. A decision to grant a VL depends on a number of factors including the severity of the HIV/AIDS epidemic in that country, local healthcare provision and the economic and manufacturing environment.... Selecting the most appropriate licensee is key. We need to be sure that the manufacturer will be able to provide a long-term supply of good-quality medicines and will implement safeguards to prevent the diversion of medicines to wealthier markets. Ibid 21.

However, a genuine pecuniary interest attaches to well-enforced voluntary licenses that makes them extraordinarily attractive to pharmaceutical companies. The licenses ensure better resource allocation and utilisation in the markets where pharmaceutical companies derive the better part of their profits: Europe, North America and parts of Asia. Voluntary licenses eliminate the production and the marketing of high cost drugs in regions that will show little or no meaningful profit.

97 Ibid.

98 For more on competition policy in relation to accessing essential medicines, see $\mathbf{J}$ Berger 'Advancing Public Health by Other Means: Using Competition Policy' in Pedro Roffe et al (eds) Negotiating Health: Intellectual Property and Access to Medicines 2005). (This article is available at <http://www.iprsonline.org/unctadictsd/dialogue/2004-06-29/2004-06-29_berger.pdf $>$. See also E Cameron (co-authored with J Berger) 'Inaugural British Academy Law Lecture - Patents and Public Health: Principle, Politics and Paradox' (19 October 2004), $<$ http://www.law.ed.ac.uk/ahrb/script-ed/docs/cameron.asp >

99 See W Lesser 'The Effects of TRIPS-Mandated Intellectual Property Rights on Economic Activities in Developing Countries' (2001), < http://www.wipo.int/about-ip/en/studies/pdf/ ssa_lesser_trips.pdf $>$ (accessed on January 6 2006). Lesser has developed an IP score that measures a country's IP system based on five variables: protectable subject matter; convention membership; enforcement; administration; cost of protection. Out of a sample of 99 countries (44 developing countries) South Africa outperformed all other 43 developing countries in the sample with a score of 7.35 on a 12 point scale - relatively high for a middle income country. Chile, with the next highest score, registered at 7.2, with Brazil third at 6.69. South Africa ranks third among developing countries in the number of PCT applications filed with WIPO (after South Korea and China). While these numbers suggest the strength of the IP regime in South Africa, Teljeur raises concerns about effective enforcement in his article. See Teljeur (note 77 above) 
actors to deliver low cost generics. What is most important for the argument of this paper, however, is that the IP regime in South Africa creates the space for a government-led industrial policy that will enable private companies to exploit voluntary agreements for the benefit of all South Africans.

\section{(iii) Fairness, Equity and Efficiency in the Public Procurement of Drugs}

We have adumbrated above the constitutional obligations imposed by the Constitution on the South African government with regard to the right to access health care services. We have also noted both the possibilities and the limitations of the international and domestic IP regimes within which the South African government must operate when devising an appropriate ART programme. In this section, we describe and then analyze the government's policy response to these imperatives and constraints.

After a disturbingly long delay, Cabinet finally announced in August 2003 that the Department of Health had been instructed to develop a detailed operational plan to provide ARVs within the public health sector by the end of September. Cabinet then convened to consider a report of the Joint Health and Treasury Task Team that spelled out the optimal available treatment options. The report concluded that changing factors, for example, new developments pertaining to the 'pricing of drugs' and the 'availability of budgetary resources [would] . . enable government to consider [these] enhanced response[s]. ${ }^{, 00}$ By 19 November 2003, the Ministry of Health produced the first plan for a national ARV rollout: the Operational Plan for Comprehensive HIV and AIDS Care, Management and Treatment for South Africa ('Operational Plan'). ${ }^{101}$

In procuring an affordable supply of low cost medicines for the public rollout, the Public Finance Management Act ('PFMA') requires good financial management and the effective and efficient use of limited resources to maximize services delivery. ${ }^{102}$ Government was thus obliged to create a tender programme that would ensure the delivery of drugs at the lowest possible price. To that end, the task team appointed by the Minister of Health for the ARV rollout recommended that the state invite all bidders and pre-qualify the companies that met the stated criteria. In response to the gazetted tender (February 2004), 41 companies

100 See Government Communications (GCIS) Press Release (8 August 2003), < http:// www.gov.za $>$.

101 Once again, we believe it is essential to acknowledge the critical role played by civil society in creating an environment that led to the transformation of government policies on ARV treatment.

102 The PFMA specifically ensures that all revenue, expenditure, assets and liabilities of those [provincial and national] governments are managed efficiently and effectively. 
expressed interest. ${ }^{103}$ This group was later reduced to eight companies that had registered their ARV products and received regulatory approval from the South African Medicines Control Council - the South Africa equivalent of the US Federal Drug Administration. In March of 2005, one year after the pharmaceutical companies were asked to submit their bids, the South African government announced the award of contracts to seven pharmaceutical companies ${ }^{104}$ that would supply the needed ARVs for a period of three years in the amount of R3.4 billion. ${ }^{105}$ The aim of the roll-out was to supply drugs to a 500,000 patient cohort by $2007 .{ }^{106}$

Consistent with the PFMA, the Operational Plan calls for a system of drug procurement that 'attempts to secure antiretroviral drugs at prices well below today's best international prices' with a view towards creating fully integrated production facilities for those drugs in South Africa. ${ }^{107}$ The Operational Plan cites the maintenance of strong intellectual property rights as essential to fostering innovation and industrial development and states that government will consider various measures to ensure access to affordable medicines:

The introduction of ARVs to the care and treatment of HIV and AIDS must comply with South African patent law and international obligations under the TRIPS agreement. However, the prices of patented and/or branded drugs supplied by the manufacturers may prevent equitable access to necessary drugs for South Africans. Recent international trade agreements and the South African law provide a number of ways to address this dilemma. Therefore, if it is deemed necessary and expedient, the government may consider the implementation of measures such as voluntary licensing, compulsory licensing and parallel importation to purchase drugs at affordable and favourable prices. $^{108}$

\section{Similarly, the National Drug Policy draws attention to:}

... the lack of equity in access to essential drugs, with a consequent impact on quality of care. Furthermore, rising drug prices, already high in international terms, gave increasing cause for concern, as did evidence of irrational use of drugs, losses through malpractice and poor security, and cost-ineffective pharmaceutical procurement and logistic practices. $^{109}$

103 See Government of the Republic of South Africa, Department of Health, Health Information, Evaluation and Research Cluster 'Monitoring Review: Progress Report on the Implementation of the Comprehensive HIV and AIDS Care, Management and Treatment Programme' (1 September 2004) 5; Recommendations of Task Team 'Comprehensive HIV and AIDS Care, Management and Treatment Programme' (2002).

104 These companies are: Aspen Pharmacare, Merck Sharp \& Dohme, GlaxoSmithKline, Abbott, Cipla, Bristol-Myers Squibb and Ingelheim Pharmaceuticals.

105 See Minister of Health Budget Speech (8 April 2005).

106 See T Smart 'South Africa Awards Antiretroviral Supply Contracts' AIDSmap (2004); Government of the Republic of South Africa (Department of Health) Operational Plan for Comprehensive HIV and AIDS Care, Management and Treatment for South Africa (19 November 2003) 240, < http://www.info.gov.za/otherdocs/2003/aidsplan.pdf > .

107 Smart (note 106 above) 38.

108 Operational Plan (note 98 above) 39-40.

109 National Drug Policy (note 15 above) 6. 
On paper, both documents suggest a far-reaching and forward-looking view of drug procurement. ${ }^{110}$ On the ground, the reality looked somewhat different.

Cabinet announced the ARV rollout in November of 2003. But by the 25th of March 2004, the Department of Health, pressed by the threat of legal action by activist organisations such as the Treatment Action Campaign, announced that they would need to purchase an emergency supply of antiretrovirals as a stop-gap measure until the formal tender process for drug procurement was concluded. ${ }^{11}$ In May 2004, drug shortages were well-documented and patented medicines unavailable. In the midst of such drug shortages, Andy Gray observed that the Government was in the unenviable position of possessing 'some generics - sitting with the Medicines Control Council for more than a year awaiting registration' - and being obliged 'to purchase [ARVs] from brand name sources' at substantially higher prices. ${ }^{112}$

The government has, however, had some success with respect to its macro-economic and macro-pharmaceutical policy. First, government's drug procurement approach must be measured against reasonable benchmarks. One such benchmark is the respective costs of drugs in the public sector and the private sector. In 2004, the basket of pharmaceutical products purchased by private health care providers came to R13 billion. In 2004, the basket of pharmaceutical products purchased by state - and made up to a significant degree by generics cost a mere R3 billion. ${ }^{113}$ The ability of the state to leverage significant savings for South Africans and the public health care system through the purchase of generics is obvious. Second, the state can take partial responsibility for the success of recent initiatives by Aspen Pharmacare ('Aspen'). A Strategic Investment Programme and the promise of a fullscale national rollout induced Aspen to invest R182 million in a

110 The drug procurement system envisaged in the Operational Plan was intended to meet five stated objectives. First, the medicines would be of the highest quality and licensed by the South African Medicines Control Council. Second, the medicines would be appropriate to the treatment regimens outlined in the Operational Plan. Third, the supply of medicines would be secure and sustainable at a volume large enough to meet the expected demand. Fourth, medicines would be purchased at the lowest possible prices. Fifth, a sustainable supply would be ensured through local production of antiretrovirals and sustainable financing. And, the Minister of Health would appoint a negotiating team to implement the procurement strategy recommended in the plan. See the Operational Plan for Comprehensive HIV and AIDS Care, Management and Treatment for South Africa (note 100 above) 144154.

111 Irin Plus News (UN-OCHA Integrated Regional Information Networks) 'South Africa: Chronology of HIV/AIDS Treatment Plan, August 2003 to April 2004' (16 November 2005).

112 See 'Antiretroviral Sources of Supply May not be Able to Meet Popular Demand' < http:// www.redribbon.co.za $>$.

113 See Department of Trade and Industry website <http://www.dti.gov.za $>$. 
manufacturing facility in Port Elizabeth capable of producing amongst other items - significant amounts of generic ARVs. ${ }^{114}$ On the back of that investment, and the 'promise' of a mass ART programme, Aspen has secured voluntary licenses from a significant number of patent-holders to produce a broad array of ARVs. ${ }^{115}$ This loose, but apparently efficacious, relationship between the public sector and the private sector answers the Operational Plan's cri de coeur - 'if it is deemed necessary and expedient, the government may consider the implementation of measures such as voluntary licensing, compulsory licensing and parallel importation to purchase drugs [for the rollout] at affordable and favourable prices, ${ }^{116}$ — without the political and economic risks associated with permissible patent-breaking measures.

It would, therefore, be incorrect to suggest that the government has done nothing by way of voluntary licenses, compulsory licenses or parallel importation to reduce drug prices. The real, and constitutionallymandated question, is whether the government has done enough to realise its public commitment and legal obligation to create a genuinely sustainable ART programme. At this stage, we believe that the government has not done so.

That more can be done is evinced, once again, by the experience of Brazil. Orsi observes that the decline in ARV prices for Brazil was a function of the role of public laboratories in local production and the willingness of the Ministry of Health to threaten to use compulsory

114 Government of the Republic of South Africa (Department of Trade and Industry)(note 21 above).

115 Aspen Pharmacare is currently producing significant amounts of first and second line ARVs, as well as multi-drug resistant (MDR) tuberculosis drugs, under voluntary licenses with Eli Lilly, GlaxoSmithKline, Gilead, Boehringer and Bristol-Myers Squibb. As the public record demonstrates, Aspen alone has voluntary licenses to produce the following drugs: 1 . Nevirapine; 2. Efavirenz/Stocrin 2. Atazanavir; 3.Tenofovir; 4. Lamivudine/3TC 5; Zidovudine; 6. Stavudine; 7. Didanosine; 8. Emcitrabine; 9. Capreomycin and 10 . Cycloserine. See RPM Plus South Africa, <http://usembassy.state.gov>. In fact, Aspen has recently reached agreement on additional voluntary licenses. These agreements are not aberrations: 93 per cent of Aspen's requests for voluntary licenses have been granted. Interview with Stavros Nicolau 19 July 2006. Given the TB epidemic in South Africa, and the complications associated with the treatment of both HIV/AIDS and TB, the recent manufacturing and technology transfer agreement between Aspen and Lupin Ltd of India to produce first and second line TB drugs complements Aspen's aforementioned voluntary licenses for ARVs. See 'Big Boost for Fight against TB' Fin24 (26 September 2005).

116 Operational Plan (note 100 above) 41. Parallel imports are cross-border trade in a patented product without the permission of the manufacturer or patent holder. Parallel imports take place when there are significant price differences for the same good in different markets and serve as a vehicle for reducing the prices for consumers in developing countries. See $\mathrm{R}$ Weissman 'AIDS and Developing Countries: Democratizing Access to Essential Medicines' in T Barry and M Honey (eds) 23 (4) (August 1999), < http://www.fpif.org > ; t' Hoen (note 81 above). Of course, parallel imports are of concern for pharmaceutical manufacturers because they permit drugs purchased at lower prices in the developing world to be resold in the developed world at substantially higher market prices. Such arbitrage naturally robs pharmaceutical manufacturers of expected profits in their primary markets. 
licenses. ${ }^{117}$ As a result of that approach — political savvy combined with a commitment to exercise the flexibilities afforded by TRIPS - Brazil's Ministry of Health has obtained a 75.2 per cent decrease on average in prices on non-patented and locally-produced ARVs. ${ }^{118}$ It has also been able to use the threat of local production to leverage substantially lower prices from multinational pharmaceutical companies. South Africa's Department of Health cannot yet make such claims.

In terms of drug pricing, the dominant rate-limiting factor in South Africa is a lack of meaningful competition amongst suppliers. ${ }^{119}$ Our primary thesis remains that the state's ARV rollout evinces a sub-optimal procurement approach because South Africa has not constructed an industrial policy that would effectively exploit the economic potential we possess. ${ }^{120}$ Because we believe that a sustainable ART programme as an effective social policy is contingent upon an industrial policy that promotes the local production of generic ARVs, it is to the lineaments of such an ideal social policy married to industrial policy that we now turn.

(b) Priming the pump: how a new industrial policy for the pharmaceuticals industry in South Africa can create the capacity for local private production of generics and provide the basis for a sustainable ART programme

In this section, we contend that the establishment of a sound generics pharmaceutical industry in South Africa is not only possible, but that it may be the only way of creating a sustainable ART programme. The kind of generics industry we have in mind differs significantly in kind from that developed by Brazil. South Africa does not possess the world's sixth largest petrochemicals industry, a state lab capable of reverse engineering APIs, pharmaceutical companies with vast experience producing generics, a knowledge transfer triangle formed by the state, academics and private technicians capable of moving from the general principles of generics to the specific requirements of production, a long history of patent non-compliance, or an odd flirtation with autarky that drives industrial policy in all sectors towards self-sufficiency. What then do we have?

117 See Parker (note 4 above); Teixeira (note 4 above); de vila Vitória (note 4 above); Orsi et al (note 26 above).

118 See Orsi et al (note 26 above) 117.

119 No law has kept the South African government from accessing more affordable medicines. The fault lies primarily with its current strategy and its ineffective implementation of that strategy. As MSF notes: 'Nothing is preventing South Africa from accessing cheaper antiretrovirals - they have the ability and responsibility to take proactive steps to provide cheaper antiretrovirals for the patients who urgently need them.' MSF Brazilian 'Generic Drugs in South Africa - The Background' (29 January 2002), < http://www.msf.org > .

120 See Lucchini et al (note 23 above). A strong nexus exists between procurement and pricing. Under extant circumstances, a procurement strategy which has as its end the supply of ARVs for the greatest number at the lowest cost would - through shared economies of scale place downward pressure on price. 
We possess a public procurement policy that, although not without limitations, secures drugs for the public sector at about 25 per cent of the price paid by the private sector. We have an intellectual property regime with sufficient flexibility to use voluntary licenses to enhance the production of ARVs and other anti-AIDS treatments. We possess a well-developed financial sector capable of identifying solid domestic investments and a sufficiently robust economy to fund them. We have a Department of Trade and Industry that (can and) must produce a sectorspecific strategic investment policy that could give our own nascent generics industry something of a competitive advantage for ARV production in an otherwise highly competitive global industry. In South Africa, the access to ARVs has no meaningful legal barrier or insuperable financial constraint.

What we have, instead, is a failure of political will as well as something of a market failure. These two impediments to a successful ARV programme can be corrected, in part, with by an appropriate socioindustrial solution: the creation of the economic environment required for a generic drugs industry for ARVs.

\section{(i) No compulsory license}

Before we explain the rudiments of an ideal industrial policy that draws on South Africa's strengths, it is, perhaps, worth spending a moment and thinking about why compulsory licenses - or the threat of compulsory licenses - are not a viable policy option for South Africa. Such an explanation is warranted when authors in this Journal, such as Thomas Bollyky, argue that by not exploiting the opportunities afforded by such licenses, the South African government is abdicating its responsibility in terms of s $27 .^{121}$

Although the use of a compulsory license does not require the capacity to produce the drug in question, issuing a compulsory license as a threat to reduce prices for patented drugs does. To meaningfully make such a threat one first requires the basic science capacity to reverse engineer the API. Pharmaceutical agents - patented or not - often have very complicated molecular structures that, as in the case of ARVs, can require between 30 and 100 or more steps of chemical synthesis. ${ }^{122}$ (Failure to accurately replicate any one of these steps will lead to an inefficacious and sometimes dangerous product.). ${ }^{123}$ The conversion

121 Bollyky (note 17 above) 566-567.

122 See Cassier \& Correa (note 31 above) 98-99; Department of Trade and Industry website, $<$ http://www.dti.gov.za $>$.

123 To get a sense of where we are, the API precursors to codeine and to paracetemol that South Africa currently imports require but one step for completion. See Department of Trade and Industry website, <http://www.dti.gov.za $>$. 
process for ARVs, and especially the newer line ARVs, is exponentially more complex.

But let us assume for the sake of argument that we had the basic science community required to reverse engineer APIs. After all, the Council for Scientific and Industrial Research (CSIR) was able to successfully produce small quantities of nevirapine in the late 1990s. ${ }^{124}$ (Unfortunately, the government was not then interested in creating the conditions for mass production.) There is, however, a palpable difference in the processes required for the production of small quantities of a generic drug, and the processes required for the mass production of that same drug. South Africa has committed itself to the production of bioequivalent drugs - an appropriately high standard. ${ }^{125}$ This exacting standard knows no shortcuts.

Why not try to create this capacity? Some South Africans have. In the 1990s, AECI, a large industrial chemicals corporation, attempted to create a vertically integrated pharmaceuticals business (for penicillin and various derivatives). Over little more than a decade, AECI only managed to manufacture lysine, an amino-acid. It lacked the technical capacity required to complete the jump from lysine to the desired antibiotics. (Moreover, it lacked the technical capacity to make the jump despite the fact that the desired antibiotics were no longer under patent. That is, the patent was not the bar to generic production - the working knowledge possessed by the original manufacturer of the antibiotics was.)

Another reason is cost. Not only is the required investment for a suitable reverse engineering lab and generics plant substantial estimates range from $\mathrm{R} 150,000,000$ to $\mathrm{R} 200,000,000$ (excluding the greenfields and tax credit expenditures that would be required from government), the cost of the final products might dramatically outweigh any benefit to be had in producing them. As it now stands, it currently costs more to source the raw materials for APIs in South Africa than it

124 Interview with Fanie Marais, CSIR, 13 January 2006.

125 Brazil has used similars in place of generics in most instances. A 2005 WHO Bulletin notes with regard to generics and similars:

'It is not enough to say that a given pharmaceutical product produces the same pharmaceutical or therapeutic effect as the original. Regulatory agencies need to ensure that manufacturing follows international standards of good manufacturing practices, and they need to ensure the quality of the pharmaceutical supply. Some authors have raised doubts about the capability of drug regulatory agencies to do so The importance of ensuring the quality of the medicines supplied cannot be overemphasized, especially in view of the increasing presence of counterfeit drugs.'

Moreover, as the article points out, the term 'generic' has different meanings within and across countries, leading to further problems of classification and regulation: 'The result is that generic drug policies relate to the use of similar drugs (or copies), and in daily speech most policy-makers, consumers, and many health professionals use the terms generic and similar interchangeably, which further confuses the issue.' See N Homedes \& A Ugalde 'Multisource Drug Policies in Latin America: Survey of 10 Countries' Bulletin of the World Health Organisation (January 2005) 83 (1). 
does to offload in Durban a finished API produced in China. Why, assuming access to those APIs continue to exist, would we wish to create more expensive APIs?

As we have already seen, questions about long-term availability of drugs from China, India and South Korea persist. But given that 70-80 per cent of the cost of an ARV is associated with the production of the APIs, ${ }^{126}$ only significant economies of scale would warrant the investment necessary to create a varied and sustainable supply. ${ }^{127}$

Putting aside for a moment the daunting hurdle of establishing a fine chemicals industry capable of producing the APIs required for ARVs, we would still need an adequate manufacturing base. South Africa does not yet possess one. As we shall see in the next section, Aspen Pharmacare has entered the breach and has created a plant in Port Elizabeth with enormous capacity - enough to supply 70 per cent of the public ARV rollout for the first three years. Other local generic manufacturers have entered the market and will compete with Aspen in the next round of government tenders. ${ }^{128}$

\section{(ii) Voluntary licenses, sector-specific investment policies and an enhanced manufacturing base}

\section{(aa) Voluntary Licenses}

Our thesis is that just about everything that can be done by compulsory licenses can be done better by voluntary licenses. Multinational pharmaceutical companies are not philanthropies. And they don't act like them. However, they do behave rationally in so far as their profits are concerned.

South Africa currently constitutes a mere 0.3 per cent of the world market for pharmaceuticals. Africa, in total, accounts for just over 2 per cent of that market. ${ }^{129}$ So while no company has any interest in selling their product for less than the market will bear, multinational pharmaceutical company profits do not turn, in any significant degree, on their share of the African or the South African markets. As a result, these companies have demonstrated a willingness to engage in differential pricing for developed countries and developing countries.

126 See Orsi et al (note 26 above).

127 One must also not forget that the ARVs in use are constantly changing in response to the resistance of new strains of the virus to current drug regimens. The cost of creating a generic that may soon pass its sell-by date may significantly outpace and outprice alternative methods of sourcing the drug.

128 Amongst Aspen's chief local competitors in the ARV generics market are Adcock-Ingram, Sonke Pharmaceuticals (Pty) Ltd., and Cipla Medpro (a joint venture between Cipla Ltd. of India and Medpro Pharmaceutica, a South African generic pharmaceutical company).

129 See Combe et al (note 40 above). 
The primary concern for multinationals is re-exportation. Multinational companies do not want to find themselves in a situation in which they have supplied drugs at favourable terms to a developing country such as South Africa, only to find those same drugs being resold at much higher prices in Europe and North America. The companies have a vested interest in preventing such arbitrage. ${ }^{130}$

Voluntary licenses secure multinationals the patent protection they require, and, most importantly, prevent the re-exportation of drugs to markets where the companies do see the greater part of the return on their investments. Best of all, they are generally free and come with the necessary technology transfers required to make effective use of the intellectual property on offer. For example, in the settlement agreements between the TAC and Boehringer Ingelheim and GlaxoSmithKline ('GSK'), GSK and Boehringer Ingelheim were willing to provide voluntary licenses for nevirapine, AZT and 3TC to Aspen Pharmacare and Thembalami Pharmaceuticals (Pty) Ltd for manufacture and distribution within South Africa and for export to 47 countries in Africa for a royalty of no more than 5 per cent of net sales. ${ }^{131}$ In the intervening four years since the TAC settlement, Aspen Pharmacare has entered into voluntary and quasi-voluntary license agreements (as well as technology transfers) with Bristol-Myers Squibb, Eli Lilly, Gilead Sciences, GSK and Boehringer Ingelheim that require no royalty payments at all. Aspen has formed a joint venture with Indian generic manufacturer Matrix - and thus secured a 50 per cent stake in Asterix - to ensure ongoing access to and future large scale production of APIs. ${ }^{132}$ Once again, these agreements demonstrate that voluntary licenses can — in the right environment - be exploited in the service of a free, universal ART programme for the treatment of HIV/AIDS. ${ }^{133}$

130 Interview with Stavros Nicolaou, Aspen Pharmacare, 28 February 2006; Department of Trade and Industry website < http://www.dti.gov.za $>$.

131 See Settlement Agreement entered into and between the twelve complainants to the Competition Commission in South Africa in terms of the Competition Act, under and in connection with case no 2002 Sep 226, and, GlaxoSmithKline South Africa (Pty) Ltd, Glaxo Group Limited and the Wellcome Foundation Limited; and Agreement between the Generic Anti-retroviral Procurement Project (incorporated under Section 21 of the Companies Act, No. 61 of 1973) and the TAC Treatment Project and Boehringer Ingelheim Pharmaceuticals Inc. See also Interview with Stavros Nicolaou (ibid).

132 Matrix is one of India's largest producers of generic APIs; Asterix is the product of a joint venture between Aspen and Matrix. Matrix is one of only two suppliers of APIs that the Clinton Foundation has approved for the supply of antiretroviral APIs. 'Aspen, Indian Firm in Drug Link' (23 September 2005) < http://www.Fin24.co.za>.

133 It is important to note, however, that voluntary licenses are not simply the product of negotiations between multinational pharmaceutical companies and generic pharmaceutical companies, nor are they primarily the result of protracted litigation. The conditions that produce voluntary licenses on the scale we currently require are complex. Civil society, for one, has played a critical role in loosening the bonds of intellectual property. For example, in March of 2001 Bristol-Myers Squibb (BMS) announced that it would offer a 'free license under the patent for Zerit (d4T) (rights to which are owned by Yale and Bristol-Myers 


\section{(bb) Sector-specific investment strategies}

The government - in the form of the Department of Trade and Industry and the Department of Health and the Treasury - are aware that a vast domestic health care market exists to be exploited by South African industry for the benefit of South Africans. The current South African share of this R110 billion market is miniscule. We currently import 65 per cent of our drugs, 90 per cent of our medical devices, nearly 100 per cent of our medical diagnostics and 100 per cent of our vaccines. The government is on record as wanting to increase South Africa's market share in those four areas both to advance the socio-economic needs of the nation and to ensure that our current trade-deficit does not worsen as the need for more expensive drugs, devices and diagnostics increases (as it surely will if all those who require ART receive it.) ${ }^{134}$

The dominant mechanisms of industrial policy in the neo-liberal framework within which we operate involve the use of financial and tax incentives to spur investment in certain sectors of the economy. South Africa uses a mix of policy incentives to induce the private sector to invest

Squibb) to treat AIDS in sub-Saharan Africa.' Both BMS and Yale had been under pressure to grant the license from Yale students, the Consumer Project on Technology and MSF South Africa. The result — as with many voluntary licenses - was a rapid, thirty-fold reduction in the price of d4T in South Africa (from more than $\$ 1600$ to $\$ 55$ per patient per year). One generic company - Aspen Pharmacare — subsequently signed an agreement with Bristol-Myers Squibb that has enabled it to make generic d4T in South Africa. Yale's change in the control of intellectual property occurred 'without any negative consequences to the University - financial or otherwise.' See A Kapczynski 'Access to Essential Medicines and University Research: Building Best Practices' (2003) Yale University Centre for Interdisciplinary Research on AIDS.

134 Industrial policy in South Africa's science and technology sector is based on the concept of a National System of Innovation (NSI). The NSI is a set of interlocking institutions and policy instruments in South Africa that advance a common set of economic and social objectives using economic incentives as the vehicle for producing change. The NSI depends on cluster and sectoral strategies, on infrastructure and on 'key enablers' such as human resources, and R\&D. South Africa's National Research and Development Strategy (R\&D Strategy) recognises the critical role that government plays in providing an enabling environment for innovation, research, and building human capital to meet South Africa's socio-economic development challenges. Government of the Republic of South Africa. South Africa's National Research and Development Strategy (prepared by Department of Trade and Industry (DTI)) (August 2002) 21. The Government also recognises that the importation of 95 per cent of all APIs which constitute up to 80 per cent of the final manufacturer's cost of a pharmaceutical product - is, over the long run, unsustainable. Interview with Stavros Nicolaou, Aspen Pharmacare, 28 February 2006. The second leading source of our current trade deficit after oil - is health-care related products. Department of Trade and Industry website, available at < http://www.dti.gov.za > (accessed on 15 January 2006). A failure to get our macro-economic policies right - because of continuing trade deficits and the lack of local production - could make it extraordinarily difficult to fund a free, universal rollout for all persons who require treatment for HIV/AIDS. 
in technological innovation projects and employment-generating industries. $^{135}$

The national Department of Trade and Industry (DTI) is responsible for fiscal incentives to encourage private sector participation in research and development. ${ }^{136}$ To this end, the DTI established clusters of Strategic Industrial Projects (SIP). SIP was designed to 'significantly contribute to growth, development and competitiveness of specific industry sectors by providing industrial investment allowances, in the form of tax relief., ${ }^{137}$ The most significant SIP project for the purposes of a sustainable ART programme involved an Aspen Pharmacare project. Aspen Pharmacare invested R182 million in a manufacturing plant in Port Elizabeth. ${ }^{138}$

That facility gives Aspen the capacity to produce sufficient first line and second line ARVs to service South Africa and, potentially, the rest of the continent. (As we have indicated above, Aspen now provides 70 per cent of the drugs for the state's current ARV programme. ${ }^{139}$ ) DTI has also approved another important SIP project that would allow for the expansion of the Roche Products (Pty) Ltd plant in Isando to achieve Good Manufacturing Practice (GMP) status. ${ }^{140}$ This status will allow Roche to manufacture an anti-malarial drug, Fansidar, for the world market and may enable Roche, eventually, to produce other essential medicines. $^{141}$

135 These programmes currently include: The Innovation Fund; the Technology and Human Resource for Industry Programme (THRIP); foreign investment grants; and export marketing and investment assistance schemes. To give firms added financial incentives, the government could provide tax deductions or credits to pharmaceutical companies to encourage research and development. The National Research Foundation also provides grants for R\&D.

136 Government of the Republic of South Africa (note 21 above).

137 Department of Trade and Industry (note 21 above). The SIP programme ran from 2000 through 2004 and was governed by article 12G of the Income Tax Act, 1962. A proposed project, to qualify for an industrial allowance, had to invest more than R50 million in South Africa and contribute to significant growth, development and competitiveness of the industry sector. Over the period April 2002 to March 2004, 25 SIP projects were approved.

138 Projections indicated that 113 direct jobs and 317 indirect employment opportunities would be created. The project was approved by the DTI on 8 December 2003 with an investment allowance of R110,559,000 and tax forfeited in the amount of R33,167,700. Department of Trade and Industry (note 21 above). Interview with Stavros Nicolaou, Aspen Pharmacare, 28 February 2006.

139 The company derives a mere 6 per cent of its revenue from the ARV rollout. Interview with Stavros Nicolaou, Aspen Pharmacare, 28 February 2006; Department of Trade and Industry (note 21 above).

140 Food and Drug Administration determine these quality controls. On February 20, 2003, the Food and Drug Administration (FDA) released its first progress report on a major initiative concerning the regulation of drug product quality. The two-year initiative, Pharmaceutical cGMPs for the 21st Century: A Risk-Based Approach (the Pharmaceutical cGMP initiative), which was launched on 21 August 2002, applies to human drug and biological drug products and veterinary drugs < http://www.FDA.gov $>$.

141 See Government of the Republic of South Africa (Department of Trade and Industry) Report to Parliament: Strategic Industrial Projects (SIP): April 2002-March 2004 (2005). 
(cc) Enhanced manufacturing capacity and a reliable source of APIs

Of course, all the manufacturing capacity in the world will be of no use whatsoever without access to the critical component of pharmaceuticals: APIs. Moreover, legitimate concerns have been raised that as the AIDS pandemic reaches India and China, those two countries will soak up all of the available APIs and generic ARVs that they produce domestically. That could leave South Africa out in the generic cold. There are, however, several possible solutions to this problem.

First, we could produce our own generics. As we have already seen, the costs of such investment are immense - if not prohibitive. That said, some investment in the ability to produce APIs may be necessary to ensure a sustainable supply of ARVs.

Secondly, we could enter into technology transfer agreements. Such agreements would not require South Africa or South African companies to re-create the wheel. South-to-south technology transfer agreements have the additional virtue of securing the benefits of innovation for developing countries and ensuring that they are not locked out of markets currently dominated by corporations located in the developed nations of the world. A number of technology transfer arrangements are well underway across the African continent to facilitate such infrastructure building, technical expertise and knowledge transfer. Brazil has given $\$ 100,000$ in technology transfer grants to five countries in Latin America and five in Africa to help develop local generics industries for ARVs. The Thai government has offered technical support to Ghana, Zambia and Zimbabwe to set up pilot manufacturing plants. (Zambia hopes to sell ARVs to 13 countries in Africa. ${ }^{142}$ ) As we have already seen, Aspen Pharamacare has secured technology transfers from most of the pharmaceutical companies from whom it has sought voluntary licenses. Moreover, the government's own Operational Plan endorses such technology transfer agreements.

Thirdly, the South African government could promote joint ventures between local manufacturers and foreign producers of APIs. Aspen entered into a joint-venture agreement with Matrix, of India, to manufacture active pharmaceutical ingredients (APIs) by selling half its share of Fine Chemicals. The joint venture and share swap gives Aspen immediate access to a panoply of APIs required to produce generics. (Aspen's share swap with Matrix gives it a 50 per cent stake in Asterix a leading producer of APIs.) By giving Matrix a significant interest in Fine Chemicals, Aspen also puts Fine Chemicals - a South African company - in a position to expand the kinds of generics it produces. With Enaleni's recent acquisition of Cipla Medpro, South Africa has the

142 See DFID Leveraging the Private Sector for Public Health Objectives (2004), < http:// www.eldis.org/healthsystems/access/index.htm $>$. 
potential to create another strong local producer of ARV generics, and with it a more competitive market. As t'Hoen and Moon emphasize, generic competition is one of the most potent instruments that policymakers have to effectively lower ARV drug prices. ${ }^{143}$

\section{(iii) Industry Fundamentals and Prospects}

On the credit side of the ledger, South Africa has the largest pharmaceutical industry on the African continent: the manufacturers' market was valued at $\$ 3$ billion in $2005 .{ }^{144}$ The country has a sophisticated transportation infrastructure, a highly developed industrial base underpinned by a modern telecommunications sector, and an economy with an average growth rate of 3 per cent per annum for the period 1995 to $2004 .{ }^{145}$ According to the annual report of the Pharmaceutical Manufacturers' Association of South Africa, 'recent evidence points to the South African generic market by value (sic) ranking as the largest among the generic markets of the world's major pharmaceutical markets. ${ }^{146}$ The industry's position on a generics industry is favourable:

It is a myth that the research based pharmaceutical industry is opposed to the use of generics. Internationally, industry believes that generics, introduced following an adequate period of market exclusivity and within an appropriate regulatory policies and processes, offers . . . consumers legitimate choices. ${ }^{147}$

The industry supports the manufacture of generic medicines within the context of a strong regulatory environment with stringent quality control procedures.

However, questions exist about South Africa's ability to train and retain a skilled workforce. First, although the state has embarked upon

143 See E t'Hoen and S Moon 'Equity Pricing of Essential Medicines in Developing Countries', adapted from a presentation made by $E$ ' $t$ Hoen of Médecins Sans Frontières at the WHO/ WTO Workshop on Differential Pricing and Financing of Essential Drugs (Hsbjr, Norway, April 2001) < http://www.wto.org > . Lucchini warns that "excessive reliance on "corporate philanthropy" and international bargaining between UN organisations and the major brandname manufacturers will not guarantee the long term sustainability of the lower differential pricing of ARVs' and contends that only multiple suppliers - and this must largely be producers of generics - can ensure continued downward pressure and thus differential prices for ARVs in countries such as South Africa. See Lucchini et al (note 23 above). See also Interview with Stavros Nicolaou, Aspen Pharmacare, 28 February 2006.

144 See IMS Moving Annual Total (December 2005).

145 WHO Innovation in Developing Countries to Meet Health Needs Experiences of China, Brazil, South Africa and India: Country Reports for submission to the Commission on Intellectual Property Rights, Innovation and Public Health (April 2005) $16<$ http://www.who.int/ $>$. The State of South Africa's Real Economy 20051.

146 The text should read volume, not value. The annual report is thus incorrect in this regard, though surely its intention was not to mislead. Pharmaceutical Manufacturers' Association of South Africa Annual Report 2002-2003 (2003) 27.

147 'Generics - Summary’ (December 2003), <http://www.sapma.co.za >. 
various interventions to address problems such as poor performance in mathematics and science and the emigration of qualified professionals, ${ }^{148}$ it will take some time for the positive effects of such programmes to be realized. Second, one intractable feature of the pharmaceutical industry is the high fixed cost associated with research and development. (In general, South African R\&D is weak: combined public and private expenditure in R\&D rests at 0.7 per cent of GDP, contrasted with a typical OECD expenditure of 2.15 per cent. ${ }^{149}$ ) However, low marginal costs of production can offset R\&D investment if access to markets - such as that for the public sector treatment of HIV/AIDS - can be ensured. ${ }^{150}$

\section{CONCLUSION}

South Africa and other developing countries would be ill-advised to rely on the philanthropic spirit of pharmaceutical companies in the form of drug donations and discounts when attempting to secure access to lifeprolonging medication. ${ }^{151}$ South Africa has the wherewithal to ensure sustainable access to such medicines through the promotion of an industrial policy that harnesses existing manufacturing capacity.

While we have seen that South Africa does not currently possess the industrial capacity required to back up the threat of a compulsory license - even if compulsory licenses were a good idea - we have, at the same time, shown that voluntary licenses with tech transfers and continued access to APIs are the preferred pre-conditions for a successful South African generics industry. Put slightly differently, we are inclined based upon the historical record - to suggest that a consultative,

148 South Africa ranks 58th in the world in terms of emigration by trained professionals. See WHO (note 129 above). South Africa's $R \& D$ Strategy observes: 'Our human resources in science and technology are not being adequately developed and renewed: We have an aging and shrinking scientific population the key research infrastructure is composed of people who will soon retire.' Government of the Republic of South Africa (note 134 above).

149 Ibid

150 See DFID 'Leveraging the Private Sector for Public Health Objectives' (2004) 9. This DFID study analysed the evidence base for domestic production and greater access to medicines in sub-Saharan Africa. It concentrated on such factors such as quality; geographical accessibility; physical availability; acceptability; affordability. It also analysed other determinants of success such as the feasibility of domestic production of medicines to combat TB, malaria and HIV/AIDS; government strategy and policy; and the market. The DFID overview study found that a hypothetical generic company producing medicines under three different scenarios could be profitable as well as price competitive. The risks and limitations included the uncertainty in achieving a market share in a regional market, dependence on imported APIs and their fluctuating costs, and the need to produce at an international standard that meets GMP. The DFID study supports our more specific claims that South Africa requires an industrial policy that exploits a range of market incentives for the investment in the requisite infrastructure and that emphasises technology transfers, manufacturing capacity and a skilled workforce. See also Department of Trade and Industry (note 122 above).

151 See Lucchini et al (note 23 above); t'Hoen and Moon (note 129 above). 
non-confrontational approach between government, local industry, civil society and multinational pharmaceutical manufacturers is likely to yield the kind of zero per cent royalty, backward technology transfers and distribution agreements that we require.

However we have also shown that we lack, as yet, a full-fledged and coherent government policy to exploit effectively our nascent ability to manufacture generics. ${ }^{152}$ Why do we need a government policy? Because over one million South Africans will soon require access to ART through the public sector - the largest ART programme in the world. This public health crisis cannot be solved solely by market forces. Such a programme may, however, flourish with appropriate support from the Department of Health and the Department of Trade and Industry. Such support, as we noted in the previous pages, embraces appropriate tax relief, investment credits, technology transfer and assured access to APIs, the private pharmaceutical industry in South Africa. More importantly, only with such support are we likely to see a local generics industry that can compete as a producer of ARVs and be in a position to meet the state's ART requirements. ${ }^{153}$

Such a strategy alone may not ensure that we have the capacity to produce all of the drugs that South Africa's current HIV-infected population requires. However, we contend that the failure of the government to pursue aggressively a policy with a high likelihood of success could well be viewed by the Constitutional Court as an abdication of the state's constitutional responsibilities under s 27 . 